\title{
La inevitable pregunta por la identidad Introducción al tema, problema y estudio de la identidad
}

A la memoria de Ignacio Martín-Baró Y en reconocimiento a la concientización cultural e histórica que llevan a cabo, con su canto y su música, nuestros amigos de Exceso de Equipaje.

Esta es mi patria: Un montón de hombres; millones de hombres; un panal de hombres' que no saben siquiera de dónde viene el semem de sus vidas inmensamente amargas...

Tomado de Patria Exacta Oswaldo Escobar Velado

los guanacos hijos de la gran puta

los eternos indocumentados los hacelotodo, los vendelotodo, los comelotodo

los tristes más tristes del mundo, mis compatriotas, mis hermanos.

Tomado de Poema de Amor Roque Dalton

\section{Introducción}

Al finalizar la guerra civil salvadoreña, con la firma de los acuerdos de paz en 1992, uno de los temas y problemas que ha venido cobrando interés en diversos 
sectores de la población —particularmente en medios estudiantiles- y una preocupación cada vez mayor en algunos círculos intelectuales del país, es el tema y problema que presenta la pregunta por la identidad nacional. Una pregunta inevitable para comprender y enfrentar la realidad nacional presente o el porqué somos y estamos asi, como también para planificar y proyectar un futuro mejor o el cómo queremos y deberíamos ser en El Salvador.

Es una pregunta cuya respuesta no es nada fácil de encontrar y responder. Sobre todo cuando ésta se vuelve legión de interrogantes. ¿Quiénes somos los salvadoreños? ¿Por qué somos así como somos y no de otra manera como son otros pueblos o naciones? ¿Puede definirse y delimitarse la identidad nacional salvadoreña? ¿Qué significa e implica ser salvadoreño? ¿Qué elementos históricos y culturales, geográficos y ecológicos, antropológicos y lingüísticos, sociológicos y psicológicos, económicos y políticos nos identifican como salvadoreños? ¿Existe de forma consciente en la población salvadoreña una identidad nacional o hay que construirla? ¿Es esta identidad nacional un fenómeno histórico y cultural homogéneo o más bien algo muy heterogéneo compuesto por toda una diversidad de elementos sociales, culturales y raciales? $i$ Es viable y sustentable hablar de una identidad nacional sin el estudio, conocimiento, conciencia y valoración de las distintas identidades locales que conforman la población salvadoreña? ¿No es más bien la "identidad nacional salvadoreña" actual una creación artificial estatal e ideológica, precisamente por no tomar en cuenta las diferentes identidades socioculturales que componen el país? Es la "salvadoreñidad", entonces, ¿una realidad o una ilusión? ¿Puede tener valor y credibilidad un Plan de nación en el que superficialmente se toma en cuenta el tema y problema de la identidad nacional de los salvadoreños? ¿Qué implica tener identidad nacional? ¿Tiene sentido seguir hablando de identidades nacionales en un mundo globalizado? ¿De qué sirve ocuparse de la identidad nacional cuando los Estados-nacionales están en crisis, por ejemplo en Europa donde se trabaja más bien en la construcción de una identidad comunitaria regional como es la Unión Europea? ¿Cómo se justifica el estudio y análisis de la identidad nacional frente al necesario e impostergable proceso de integración regional en Centroamérica? ¿No será necesario abandonar el concepto tradicional de identidad nacional ligado a nacionalismos enfermizos y peligrosas manipulaciones ideológicas gubernamentales- y fomentar más bien una noción y construcción de identidad nacional acorde a la sociedad regional y globalizada que reclama el tiempo llamado "postmodemo" que vivimos mundialmente, lo que significa abrirse a un diálogo e intercambio intercultural regional e internacional?

La pregunta por la identidad o por el ser colectivo nacional no es nueva en el país. De un modo u otro, implícita o explícitamente, siempre ha estado presente en las mentes y corazones de muchos salvadoreños de generación en generación, desde que este suelo y sus habitantes se convirtieron en una república o Estadonación. 
Lo novedoso de este interés y preocupación no radica, por tanto, en la pregunta en sí, sino en el contexto histórico y cultural en que ésta se hace o rehace y que la vuelve, por ello, una pregunta todavía más inevitable: una coyuntura política y otra económica, la una en el seno de un contexto nacional y la otra dentro de uno internacional, pero ambas completamente nuevas para los salvadoreños. En lo político la transición hacia la democracia. En lo económico el proceso de globalización.

La pregunta se plantea en el interior de una transición hacia la democracia que, en principio, supone y posibilita una mayor libertad de pensamiento y acción para intentar responderla a partir de una búsqueda filosófica y científica que sea lo más crítica y objetiva posible; y no desde los intereses e interpretaciones de un grupo o clase social y cultural dominante y privilegiado; mucho menos desde un nacionalismo partidarista y patriotero, futbolero y "folkclorista" como es tradición y costumbre hacerlo en el país. Sí, una búsqueda que posibilite un diagnóstico de lo que somos y un pronóstico de lo que podemos llegar a ser. Además, que fomente la creación de una identidad nacional consciente en la población, acorde a los desafíos de la sociedad globalizada y postmoderna. Una identidad nacional basada en el conocimiento, valoración y fortalecimiento de las diversas identidades locales que componen la población salvadoreña. Una identidad nacional que propicie un nacionalismo sano, maduro y crítico y, por ende, protector de lo original y endógeno pero siempre abierto a lo nuevo y exógeno, a los cambios y los intercambios con otros pueblos, culturas, naciones y regiones.

Y en lo económico, la pregunta se expone bajo el fenómeno mundial de un proceso de globalización de los mercados. Un proceso que impone y reclama, a todas las culturas y naciones de la Tierra $\longrightarrow$ que en el futuro deseen sobrevivir a las desigualdades e injusticias que reinan en el mercado internacional globalizado - un necesario conocimiento y afirmación de lo propio y particular. ¿Para qué? Para abrirse con mayor dignidad y seguridad a lo ajeno y diferente que trae consigo, inexorablemente, el intercambio comercial y cultural de la globalización económica.

Entonces, introducir al lector al tema, problema y estudio de ese fenómeno socio-cultural e histórico, que es la identidad, en general, y al de la identidad nacional salvadoreña y regional latinoamericana, en particular, es el propósito de este artículo que hoy iniciamos con un primer texto, y que se completará con dos más. En los siguientes se espera aproximar al lector a diferentes elementos y tópicos como son: la adquisición de la identidad personal y social; la identidad étnica; los conceptos cultura, raza, mestizaje, historia; la ideación, formación y desarrollo de los Estados-nacionales; las identidades nacionales frente a los desafíos de la postmodernidad, la globalización, la mundialización y la interculturalidad, etc.

Tanto éste como los artículos que seguirán se publican con fines pedagógicos provisionales, pues la carga académica como catedrático universitario nos impo- 
sibilita dedicar más tiempo y esfuerzo a estas investigaciones. Por consiguiente, la trilogía de escritos que comprenderán este ensayo sobre la inevitable pregunta por la identidad, debe tomarse nada más como una herramienta didáctica auxiliar que puede servir temporalmente a estudiantes, maestros y público en general como invitación a reflexionar y como introducción al conocimiento de la identidad nacional y regional. Por tanto, con estos textos se espera paliar, momentáneamente, la demanda de información y conocimiento que existe en este campo en nuestras universidades y colegios, debido a la falta de un material bibliográfico sistemático al respecto. Pues, en El Salvador no hay, en la actualidad, libros didácticos en los que se introduzca, estudie y analice, filosófica y científicamente, el tema y problema de la identidad nacional.

Para cerrar esta presentación debo decir que estos artículos están dedicados a la memoria de Ignacio Martín-Baró, a quien personalmente tuve la dicha de conocer y tratar y a quien, además, le debo haberme introducido e interesado, a finales de los años ochenta, en la temática y problemática de la identidad nacional salvadoreña.

En lo que tengan de valor y utilidad, por consiguiente, dedico estos escritos a su recuerdo. Y no sólo por el respeto y cariño que le guardo como persona, intelectual, catedrático y sacerdote, o por mi deuda con su obra psico-social, sino más bien por el amor y esperanza, por la luz y el ánimo que, convencido estoy, aún sigue irradiando y proporcionando al pueblo salvadoreño a través de su recuerdo y su obra, a la par, por supuesto, de tantos otros que como él igualmente sacrificaron sus vidas únicas e irrepetibles en la búsqueda de una sociedad más justa y digna para todos los que poblamos y deseamos vivir lo más humana y dignamente posible en El Salvador.

Y también porque, como afirma el sociólogo español José María Mardones, "la solidaridad del recuerdo con estos hombres y mujeres funda la posibilidad de crear formas de vida más humanas y felices". Pues "sólo recordando la historia desde el punto de vista de los vencidos y muertos por la felicidad de los otros y ejercitando la compasión solidaria, crearemos formas de vida plurales y más humanas y nos preservará de la trivialidad"'.

Asimismo, este trabajo es un reconocimiento al grupo Exceso de Equipaje, cuyos miembros son músicos académicos y artistas comprometidos con un trabajo de concientización sobre la realidad histórica y cultural nacional.

\section{Concepciones $\mathbf{y}$ niveles de estudio sobre la identidad}

Identidad se opone a alteridad, aunque ambos conceptos y las realidades que denotan estén íntimamente ligados. Así tenemos que el término identidad es. definido por los diccionarios en varios sentidos: 
- Como calidad de lo idéntico o como carácter de lo que es idéntico.

- Lo idéntico como lo totalmente igual.

- La identidad como algo que es lo mismo o como aquello que tiene similitud y unidad.

- Lo que permanece a pesar de los cambios que sufre con el llamado paso del tiempo.

- La identidad, se trate de una persona o de una comunidad humana, presenta unos rasgos comunes y particulares que proporcionan una personalidad propia.

Esta última definición es la que más se acerca a los intereses de este artículo. La identidad de un individuo o de una colectividad es lo que personaliza y distingue de otros. Identidad es, por ello, lo opuesto a alteridad. La alteridad es el otro o los otros, es decir, la mujer o el hombre distinto a mí o la cultura o la nación diferente a la mía.

El término identidad no sólo es complejo sino también polémico. Para ocuparse de su estudio es necesario, primero, precisar desde qué realidad, saber, enfoque y nivel se analiza. Porque no es lo mismo tratar la identidad a partir de la antropología que desde la sociología, como diferente será abarcarla con la psicología que con la filosofía. Son estos saberes y enfoques de estudio particulares que terminan guardando, de alguna manera, sus distancias y especialidades respecto a este problema; sin embargo, es necesario interrelacionar todos estos saberes para lograr un estudio completo y sistemático sobre el fenómeno de la identidad. Asimismo, tenemos que cambiar totalmente la cuestión de la identidad si nos referimos a sus niveles de posible estudio en tanto que realidad sociocultural. Pues, según los autores, puede ser distinto hablar de identidad personal que de identidad grupal, de identidad social que de identidad cultural, de identidad étnica que de identidad nacional. Todas estas ideas expresan diferentes niveles de realidad de la identidad humana y varían según sea el saber, la teoría y el autor que los investiga. El problema de la identidad, por consiguiente, reviste varios planos de estudio y su análisis puede realizarse partiendo de muchos campos y especialidades. A nosotros nos interesa la identidad nacional como concepto y como fenómeno socio-cultural.

No obstante, ocuparse de la identidad nacional hó significa, en ninguna forma, saltarse y despreocuparse de los otros planos como son la identidad personal, la identidad grupal, sea ésta social, cultural o étnica. Primero, porque si se quiere conocer e investigar con seriedad y rigor, esto es de manera filosófica y científica el problema de la identidad nacional de un país, para determinar la verdad o falsedad, la realidad o ilusión de su identidad colectiva, es imprescindible analizar o al menos tomar de alguna manera en cuenta los otros niveles de realidad de la identidad. Segundo, porque la identidad personal, grupal, social y 
cultural o étnica tienen, para unos especialistas, mayor grado de validez que la identidad nacional; mientras que para otros son la única, real y verdadera identidad, ya que consideran la llamada identidad nacional como pura ficción y fantasía en cualquier Estado-nación ${ }^{2}$.

Al respecto, el psicoanalista mexicano Enrique Guinsberg sostiene que "si bien es cierto que la identidad es un término de esos que parecen simples y que dicen mucho sin que sea así, las dudas sobre su existencia o valor responden a la ignorancia sobre su importancia..."

Citando ciertas fuentes, Guinsberg señala que la identidad personal puede definirse como "la persistencia de un individuo como unidad viviente distinta y diversa de las demás a través de las modificaciones que se producen en el curso de la vida". Y considera que "esto es similar para las sociedades, naciones y culturas". Por tanto, la identidad puede entenderse, según este autor, como "la configuración de una personalidad definida y, en el caso de la identidad nacional, la de una personalidad colectiva definida".

Aunque advierte: “... es preciso dejar claro que tal resultante es el producto visible de múltiples contradicciones internas (en el caso de los sujetos psíquicos) y de un conjunto de aspectos compartidos en un sentido general en el caso de un grupo social (con múltiples variaciones individuales y sociales de acuerdo a regiones, sectores, clases, ideologías, etc)..."4.

A este respecto, el psicólogo social salvadoreño, Ignacio Martín-Baró, argumentaba que "la importancia decisiva que para la organización de los grupos y personas tiene en la historia contemporánea esa particular división de la sociedad humana que son los países o naciones, ha llevado a los científicos sociales a asumir la existencia de una identidad nacional. El supuesto es que las personas que forman parte de la población de un país poseen un conjunto de rasgos comunes entre sí y distintos a los habitantes de otros países y naciones. Adicionalmente se piensa que estas características comunes sirven de vínculo de unión entre los que las poseen, que forman parte así de un grupo nacional: se es salvadoreño o alemán, marroquí o vietnamita"s.

Y para otro experto en esta materia, como es el filósofo y antropólogo guatemalteco Antonio Gallo Armosino - a quien también debo muchísimo en las investigaciones que llevo a cabo sobre la identidad salvadoreña-, si bien es cierto que "la verdadera identidad sólo se da a nivel de grupo étnico", esto no significa, afirma Gallo, que no exista una identidad nacional o que no pueda construirse una en un determinado país, pues ésta es también un modo de identidad, sólo que más global, es decir conformada no por un grupo étnico, sino por una serie y variedad de grupos sociales, culturales o étnicos que, en su conjunto, forman un Estado-nación. Y lo importante, sostiene Gallo, y que es vital y necesario tenerlo muy en cuenta, sea para El Salvador o para cualquier otro país, es que en toda nación o Estado-nación deben o deberían "reforzarse las identida- 
des locales", o sea los diferentes grupos culturales y sociales que comprenden la población de un país, "para crear una identidad nacional pluricultural" y, por tanto, verdadera. Porque "una identidad nacional a nivel de Estado-nación, sin bases de identidad local, no puede darse ni fundamentarse"6.

En otras palabras, una identidad nacional oficial, es decir la que es construida y manipulada a partir de unos intereses ideológicos estatales y gubernamentales y con base en los prejuicios de clase de los grupos que detentan el poder económico, social y político en una nación, es una identidad artificial y falsa. Pues ésta carece de un verdadero fundamento estructural cultural real, ya que la mayoría de las veces sólo es sostenida por la explotación de una ideología como es el nacionalismo.

¿El nacionalismo una ideología? Veamos: "Si una ideología es un modo general de pensar sobre el mundo que tiene consecuencias prescriptivas para la política, entonces el nacionalismo es una ideología y, con mucho, la ideología más poderosa del mundo. Como modo de pensar el mundo, acentúa la importancia de las naciones en su explicación del desarrollo histórico y su análisis contemporáneo de la política, y proclama de un modo característico que el carácter nacional es un factor determinante en la diferenciación de los seres humanos. El nacionalismo implica necesariamente que todos los seres humanos deben tener una única nacionalidad y que ésta debe ser la fuente primaria de su identidad y lealtad. Esto significa que las personas se consideran a sí mismas como miembros de una nacionalidad antes que miembros de un grupo más pequeño - un grupo social, cultural o étnico-, más inclusivo o más limitado, y que deben estar dispuestos a hacer cualquier sacrificio necesario para defender e impulsar los intereses de la nación a expensas de cualesquiera otros intereses"”. Pues el nacionalismo se ha basado, como afirma el especialista Ernest Gellner, en un principio fundamental: "Un principio político que sostiene que debe haber congruencia entre la unidad nacional y la unidad política"'. Y esto -tema que trataremos con más detalle en los siguientes escritos- ha conducido casi siempre a los Estados-nacionales a crear identidades nacionales uniformes.

Sí, ha sido un error de gran número de estados y gobiernos no tomar en cuenta la base estructural pluricultural de sus poblaciones a la hora de crear sus identidades nacionales; por ello, tales identidades han carecido de realidad y han tenido que ser siempre alimentadas por nacionalismo patrioteros, folcloristas, populistas y hasta futboleros. Y es de lamentar que desde la constitución de las monarquías nacionales en Estados-nacionales en Europa - proceso que se extiende por lo menos desde el siglo XVI hasta el XIX, y sobre todo con la expansión de la idea napoleónica de nación por el resto del mundo-, se cayó precisamente en ese error que previene Gallo. Un error que tristemente se imitó y repitió en la mayor parte de países de América Latina. Porque en el grueso de los Estados-nacionales latinoamericanos siempre se ha querido y pretendido, 
desde nuestras independencias como repúblicas soberanas, crear identidades nacionales monoculturales y unidimensionales en nombre y a favor de los intereses y prejuicios ideológicos de los grupos dominantes, criollos en unos países y mestizos en otros, en detrimento y desprecio de la realidad pluricultural de nuestras sociedades y culturas nacionales, compuesta por millones de indígenas y afroamericanos.

Es por ello que el antropólogo mexicano Guillermo Bonfil Batalla afirma: "Aunque los latinoamericanos gritamos orgullosos nuestra condición de mestizos, en buena medida vivimos de espaldas al indio. Lo hemos vuelto sólo pretérito, algo cuyo único destino es terminar, incorporarse ya para que nuestros sueños de nación se cumplan. Porque seguimos soñando con naciones homogéneas, con una sola cultura, una lengua, una raza; naciones como las quería, o las requería, el estado napoleónico. Veintitantos estados en busca de nación""

Buscando definir, entonces, el concepto identidad nacional, encontramos que la psicóloga venezolana Maritza Montero la entiende como "el conjunto de significaciones y representaciones relativamente permanentes a través del tiempo que permiten a los miembros de un grupo social que comparten una historia y un territorio común, así como otros elementos socio-culturales, tales como el lenguaje, una religión, costumbres e instituciones sociales, reconocerse como relacionados los unos con los otros biográficamente" "1".

El historiador hondureño Marvin Barahona la describe como "la conciencia compartida por los miembros de una sociedad respecto a su integración y pertenencia a una comunidad social específica, que posee un marco de referencia espacial y temporal determinado, que se forja a sí misma en un ambiente social y unas circunstancias históricas también específicas"'!.

Por nuestra parte, la identidad nacional la definimos como un fenómeno socio-histórico originado por una serie de circunstancias nacionalistas impuestas en un determinado territorio y sus poblaciones, cuyos grupos e individuos forman una sociedad nacional y asumen consciente o inconscientemente los diferentes elementos que componen su estructura cultural nacional. Y como realidad histórica que personifica, la identidad nacional puede ser verdadera o artificial, consciente o inconsciente entre los miembros y elementos que componen una nación. Verdadera, si ésta se basa en el conocimiento, reconocimiento, respeto y fortalecimiento de los diferentes grupos sociales, culturales y étnicos de la población. Artificial, si no se reconoce esta diversidad de manifestaciones humanas y si la unidad de la sociedad nacional se mantiene sólo ideológica, publicitaria y forzadamente. Consciente, si la pluralidad de grupos que componen la nación se conocen, reconocen, respetan y solidarizan críticamente como sociedád diversa pero unida, y si entre ellos hay vínculos y referentes de pertenencia a la estructura cultural nacional, un sistema pluricultural que valoran, protegen, fundamentan y proyectan con esfuerzo, orgullo, seguridad y sentido de cara a un futuro mejor. 
"La cultura como conjunto de elementos dinámicos que pueden ser transferidos de grupo a grupo y en su caso aceptados, reinterpretados o rechazados, por grupos sociales diversos"14.

\section{Sobre porqué la pregunta por la identidad es inevitable}

La pregunta por la identidad es inevitable tanto para un individuo como para un pueblo que ha alcanzado o quiere alcanzar un cierto grado de madurez. Una madurez que exige conocimiento, valoración y fundamentación de su yo personal o de su yo social para saber quién es, por qué es así como es y no de otra forma, y sobre todo para saber desde su historia presente y concreta cómo puede llegar a ser mejor según sus posibilidades y esfuerzos reales de realización. Y esta pregunta inevitable debe hacerse o debería hacerse no una ni ciertas veces, sino de forma constante y permanente tanto en los individuos como en las culturas, naciones y regiones a lo largo del desarrollo de sus vidas. Pues, los humanos somos realidades culturales psico-biológicas sujetas al devenir y, por ello, siempre en movimiento y cambio, o sea siempre en proceso. Por eso, en la naturaleza humana nada es fijo, determinado y absoluto. Mujeres y hombres somos animales inacabados, inconclusos, siempre haciéndonos en el tiempo como personas, sociedades, culturas, naciones, regiones y mundos.

La pregunta por la identidad es un alto obligado en el andar consciente de toda nación que quiera diseñar y construir de manera razonada, crítica y planificada su historia presente y futura para salir de los supuestos designios del azar y la fatalidad. Pues un país sin conciencia, valoración y fundamentación de su identidad nacional es un pueblo a la deriva, condenado a volverse cualquier cosa, inclusive a perecer, pero jamás a ser verdaderamente él mismo. Y la conciencia, valoración y fundamentación de la identidad o del ser colectivo de una nación sólo se adquiere por medio de la investigación y el estudio, de la educación y la difusión del conocimiento de los componentes de su estructura cultural nacional. Es decir del conocimiento de sus fronteras, de su espacio geográfico y ecológico, de su sociedad plural y diversa, de su economía, de sus mentalidades colectivas, tradiciones y costumbres, de su historia común.

Sí, una nación sin identidad es una sociedad sin vida propia. Es una colectividad que existe pero sin vivir plena y conscientemente su historia común y su rica diversidad de manifestaciones y elementos culturales, tanto materiales como espirituales autóctonos. Es una comunidad, pero sin comunión ni solidaridad y, por ello, forzada y resignada a vivir, sus miembros, unos junto a otros en lugar de unos con otros inmersos en un proyecto común de vida. Es un pueblo desraizado por carecer de memoria histórica y por no cultivar crítica y dinámicamente sus tradiciones y valores. Es un país en el que su gente no sabe ni le interesa saber cuáles son sus orígenes y raíces culturales e históricos, por lo que vive un presente aparentemente infinito y quizá muy divertido en medio del 
consumo, el utilitarismo y el inmediatismo tan característico en los estilos de vida postmodemos, pero no obstante es un presente oscuro y efímero, sin sentido ni futuro. Pues sólo un pueblo que tiene una identidad verdadera - por estar consciente de su pasado y porque se identifica con los suyos amando, valorando, estudiando y protegiendo de forma crítica y racional el universo natural, cultural y social en el que vive- puede tener un presente sólido y crear "planes de nación" con sentido y futuro.

Sin conocimiento, valoración, fundamentación y conciencia de su identidad, una nación no puede apropiarse, verdaderamente, de todas las posibilidades de transformación, progreso y autorrealización histórica que le ofrecen sus recursos humanos y culturales, ecológicos y geográficos, materiales y espirituales. Porque sin identidad no hay raíces que sustenten y alimenten un pueblo. Sin ella, no hay vínculos ni referentes históricos, culturales y naturales por valorar, proteger y difundir, los cuales proporcionan un sentimiento de pertenencia y, además, de orgullo y seguridad para el presente y futuro de una nación.

Pero, ¿qué significa e implica preguntar por la identidad cultural e histórica de un pueblo, entendiendo por tal una república o Estado-nación? Significa e implica preguntar por el presente de una nación; un presente en el que anida el pasado que lo ha posibilitado y determinado y que a la vez lo hace comprensible, así como un futuro que se puede planificar y que es con trabajo y dedicación potencialmente realizable. Es también preguntar por muchas cosas más. Por sus habitantes: las personas y los grupos sociales y culturales diversos que le dan unidad como cuerpo o población. Por las conductas, costumbres, valores, creencias religiosas y normas morales que conforman su alma o idiosincrasia. Por las fronteras que lo delimitan y separan de otros pueblos; pero que a la vez son también fuente de paso, intercambio y unión con otras naciones y culturas. Por sus ecosistemas y su biodiversidad: la tierra, la fauna, la flora, los ríos, lagos y mares que lo sustentan y condicionan geográficamente. Por sus invenciones artísticas, literarias, arquitectónicas, gastronómicas, científicas, poéticas, artesanales, filosóficas, tecnológicas o jurídicas que engrandecen y materializan su espíritu. Por sus tradiciones y por la memoria, cultivo y estudio de éstas, que fundamentan y prolongan su ser colectivo en cada generación. Por un conjunto de elementos afines que en lugar de igualar y uniformar a sus miembros deben o deberían integrarlos y unirlos en un proyecto común de vida. Por un conjunto de manifestaciones culturales e históricas tanto materiales como espirituales, tanto "buenas" como "malas" que lo identifican como pueblo y lo diferencian de otros, haciendo de él una realidad socio-cultural muy particular en un tiempo y espacio determinados, desde unos orígenes fundacionales hasta el presente vivo en que está. Por su economía, sus producciones y servicios, su comercio o por el bienestar y desarrollo humano y social de su gente. En fin, es preguntar por aquello que lo personaliza como estructura histórica-cultural nacional, compuesta por un con- 
junto de partes que le dan existencia, unidad y sentido y que lo hacen diferente de otros países o naciones.

La identidad es, por tanto, un tema y problema muy amplio y complejo. Abarca una gran variedad de cosas, fenómenos, situaciones, expresiones, creaciones, manifestaciones. Tiene muchas dimensiones. Su análisis, para que sea lo más completo posible, implica diferentes estudios y enfoques filosóficos, científicos o artísticos que deben integrarse.

Más que una moda su tema se ha vuelto, internacionalmente, un problema capital no sólo para filósofos, científicos o políticos, sino para pueblos enteros en el marco de los procesos de integración, globalización, interculturalidad y mundialización que se experimentan en el mundo postmodemo. Además, la guerra entre diferentes grupos étnicos en los Balcanes (bosnios, serbios, albanokosovares, montenegrinos, croatas, etc.) o en Euroasia (rusos contra chechenos) muestra la importancia y seriedad que está despertando cada vez más el tema de las identidades culturales y nacionales.

El famoso antropólogo francés Claude Lévi-Strausse anunciaba ya en los años setenta, en el Seminaire Interdisciplinaire sobre L'identité en el Collége de France (1974-1975), que la "crisis de identidad" era "el nuevo mal del siglo". Porque "cuando se hunden hábitos seculares, cuando desaparecen modos de vida, cuando se evaporan las viejas solidaridades, resulta por cierto muy fácil que se produzca una crisis de identidad"'s.

Los problemas de identidad que parecían propios de Latinoamérica y el Tercer Mundo - como destaca el famoso filósofo y jurista italiano Norberto Bobbiotambién "son ahora problemas del Primer Mundo", porque Europa y los demás países "desarrollados" son ahora un mundo que "ya no se siente seguro de su identidad"16. Tal situación ha conducido al no menos conocido filósofo alemán Jürgen Habermas a plantearse el problema de las identidades colectivas históricamente surgidas por el nacionalismo, $y$ a analizar las identidades nacionales $y$ postnacionales en el contexto social, político y económico que impone la presente coyuntura intemacional de la globalización y la mundialización $n^{17}$.

No obstante, histórica y culturalmente para el pensamiento europeo, la identidad no es ni ha sido un tema que se presente como problema filosófico existencial ${ }^{18}$. El suyo más bien ha sido el de la alteridad, es decir el problema del "otro", el de las culturas no occidentales, el de los pueblos no europeos. Y esto - - en la mayoría de los casos y sobre todo en el pasado- no se ha dado para reconocer al otro sino más bien para la destrucción y "la negación del otro en su alteridad"19, como prueba el etnocidio cometido por españoles y portugueses, ingleses y franceses con las culturas y civilizaciones americanas. Etnocidio proseguido, desgraciadamente, por criollos y mestizos, es decir por nosotros los latinoamericanos después de las independencias y perpetuado hasta el presente de muchos modos y maneras en el continente. 
En América Latina, en cambio, la pregunta por el ser colectivo es y ha sido histórica y culturalmente algo inevitable. Los latinoamericanos, o mejor dicho los indo-afro-latinoamericanos, somos una familia humana de semillas, troncos e injertos diversos. La came y el alma de nuestra identidad continental polifacética tiene sus orígenes en raíces maternas indígenas en las que a su vez se enredan raíces africanas, y también en raíces paternas europeas. A las primeras siempre por ignorancia las hemos despreciado. A las segundas, en cambio, siempre las hemos imitado pero, a su vez, siempre nos han despreciado. Y debido a estos antiguos prejuicios raciales y socio-culturales heredados, el ser frutos de un mestizaje biológico y cultural no lo hemos vivido ni descubierto aún los latinoamericanos como riqueza y grandeza, sino más bien como subdesarrollo y pobreza. Queremos ser lo que no somos. No reconocemos ni aceptamos lo que somos. Vivimos copiando, calcando, imitando y emulando a otros. $Y$ esto es la causa esencial de nuestros traumas y complejos identitarios.

Por estas razones, la cuestión de la identidad en América Latina es un tema y problema filosófico existencial que ha venido tratándose desde los primeros momentos del "descubrimiento" y conquista del continente y sus poblaciones. Y no porque la identidad cultural e histórica de esta Nuestra América -como la llamaba el prócer cubano José Martí-inicie con el "descubrimiento" y la conquista española y portuguesa, sino porque tras estos sucesos los europeos encubren y eliminan las identidades múltiples de las culturas y civilizaciones originales de América, y, a la vez, porque los sobrevivientes de estas culturas y civilizaciones, convertidos "todos" en "indios", comenzaron a plantearse la pregunta por su identidad destruida y arrebatada por el conquistador y por la nueva que el colonizador y evangelizador les imponía.

Sí, en el siglo XVI, al encontrarse y enfrentarse los conquistadores europeos con las culturas y civilizaciones americanas, se preguntaron por la identidad de esos desconocidos y misteriosos habitantes. Desde los tiempos de Colón, los llamaron por error "indios" y con desprecio los calificaron de "bestias", tal como los nombró Ginés de Sepúlveda en su Tratado sobre las causas justas de la guerra contra los indios ${ }^{21}$, pues se decía que no tenían alma, que no eran humanos. No fue sino hasta 1537 que se les reconoció su humanidad, cuando el papa Paulo III declaró que los "indios son verdaderos hombres"21. Sin embargo, tras este "reconocimiento" que en el fondo negaba la alteridad del "indio", los debates recrudecían sobre sus orígenes, marcados por los más grandes prejuicios del cristianismo medieval y por las más fabulosas fantasías renacentistas: que si descendían o no de Adán y Eva; que si provenían de las diez tribus perdidas de Israel; que si Quetzalcoatl era o no nada menos que el apóstol santo Tomás; que si eran o no originarios del mundo perdido de la Atlántida... Mientras tanto, la conquista avanzaba sometiendo militarmente cada vez más a más "indios", y la sociedad colonial se instalaba e integraba los "indios" a su régimen por medio de la cruz y de la espada. Y aquello fue una "integración" que se hizo "a precio de la vida 
y de la identidad propias"22 de los indígenas. De este modo fueron diezmados, desraizados y esclavizados. La aniquilación de su identidad cultural e histórica autóctona fue casi total. Los que sobrevivieron a este etnocidio continuaron desarrollando sus identidades étnicas bajo circunstancias injustas e inhumanas en los llamados "pueblos de indios", reductos en los cuales colonizadores y evangelizadores los confinaron y concentraron ${ }^{23}$. $Y$ hay que reconocer que su situación no mejoró tras la independencia y creación de las naciones latinoamericanas, pues más bien puede decirse que continuó siendo la misma y hasta en algunos casos empeoró —al perder los "indios" la cierta protección que la Corona Española les ofrecía - al caer en las manos de criollos y mestizos.

Sí, una vez establecido el régimen colonial en Centroamérica, bajo un sistema estratificado social y racialmente, la pregunta por la identidad se volvió todavía más inevitable entre las diferentes clases y grupos que componían la pirámide social colonial, conformada en su base por los "indios" y la población africana, y luego seguida en su orden por estratos superiores formados por ladi$\operatorname{nos}^{24}$ y mestizos, hasta llegar a la cúspide de la misma en la que residía el mundo de los blancos: criollos y peninsulares. Y en el funcionamiento de esa estructura clasista y racial en la que el peninsular oprimía y reprimía al criollo y a los otros grupos, y el criollo hacía lo mismo en contra del mestizo, el ladino, el negro y el indio, y el mestizo a su vez contra el ladino y el indio, y el indio contra el indio, y el negro contra el negro, no había ni podía haber entre tantos antagonismos, rivalidades y prejuicios etnocéntricos y raciales unidad en esa diversidad socio-cultural. Una confusión identitaria reinaba en la sociedad colonial. No sólo "traumas y fracturas irreversibles"2s, sino a la vez serios complejos de inferioridad y superioridad social y cultural se dieron y desarrollaron entre unos grupos respecto de los otros en cerca de trescientos años de vida colonial; complejos que no se quedaron en el pasado, sino que han transitado desde ese entonces hasta el momento presente en la psiquis colectiva de las poblaciones latinoamericanas.

De este modo, casi trescientos años después de la conquista, el Libertador Simón Bolívar, uno de los primeros en iniciar la pregunta por nuestra identidad regional, en una carta hecha en Jamaica el 6 de septiembre de 1815, reflexionando desde su condición criolla, se preguntaba inevitablemente por la identidad latinoamericana a las puertas de la independencia política de España: "Nosotros somos un pequeño género humano; poseemos un mundo aparte... No somos indios ni europeos, sino una especie media entre los legítimos propietarios del país y los usurpadores españoles" $26 . .$. "Somos el caso humano más extraordinario y complicado"27. Pues, "tengamos presente que nuestro pueblo no es el europeo ni el americano del Norte... Es imposible asignar con propiedad a qué familia humana pertenecemos. La mayor parte del indígena se ha aniquilado, el europeo se ha mezclado con el americano y con el africano, y éste se ha mezclado con el indio y con el europeo. Nacidos todos del seno de una misma madre, nuestros padres 
diferentes en origen y en sangre, son extranjeros, y todos difieren visiblemente en la epidermis; esta desemejanza trae un reato de la mayor trascendencia"23.

En efecto, desde la conquista y a lo largo de trescientos años de vida colonial y los casi doscientos años de vida republicana que han seguido, la pregunta por la identidad en Nuestra América no ha cesado. Ésta se ha vuelto una pregunta filosófica fundamental para el ser indo-afro-latinoamericano.

Y en esta era de integraciones regionales y globalización de las economías nos atrevemos a decir que el tema y problema de la identidad latinoamericana se ha acentuado todavía más, con una fuerza e importancia quizás jamás vista y sentida en toda nuestra historia. Pues, sin conocer y experimentar la modernidad ilustrada y su progreso -como la han vivido los estados nacionales europeos-, la mayoría de nuestros pueblos latinoamericanos - en los que no se ha consolidado y desarrollado todavía un verdadero Estado-nación, y en muchos de los cuales apenas se está pensando en crear y poner en práctica "planes de nación"- son "naciones" que se encuentran de repente en un mundo postmoderno, un mundo en el que se cuestiona la idea misma de los estados nacionales y se trabaja más bien en la construcción de identidades y comunidades regionales.

En otros términos, para los habitantes de las naciones latinoamericanas, y sobre todo para los de un país como El Salvador, la pregunta por la identidad se justifica y se vuelve inevitable por ser un problema filosófico existencial colectivo del que depende, en gran medida, nuestro presente y futuro.

Al entrevistar al filósofo y jurista nicaragüense, Alejandro Serrano Caldera, sobre el porqué la pregunta por la identidad en los países latinoamericanos resulta inevitable, nos proporcionó tres razones esenciales:

- "Porque en América Latina la pregunta por la identidad no tiene por raíz una vanidad superflua sino una necesidad ontológica".

- "Porque no puede haber identidad nacional en un país sin una unidad cultural-nacional basada en la asimilación y síntesis consciente de toda una diversidad de expresiones culturales, sociales y políticas que lo conforman".

- "Porque a los latinoamericanos la universalidad nos estará negada hasta tanto no hayamos resuelto en la teoría y en la práctica el problema de nuestra identidad colectiva multirracial y pluricultural"2y.

\section{Estudios sobre la identidad en Centroamérica'y EI Salvador}

En cada uno de los países del área centroamericana hay varios libros en los que se analiza el tema y problema de sus correspondientes identidades nacionales $y$, en ciertos casos, el de la identidad centroamericana y latinoamericana en general. Algunas de estas obras son texto de estudio en colegios y universidades, como sucede por ejemplo en Costa Rica. Y entre los libros centroamericanos de 
más reciente publicación, y que me ha sido posible obtener y consultar, cito y recomiendo los siguientes:

- En Guatemala, de Antonio Galo Amosino, Identidad nacional, Universidad Rafael Landívar, Guatemala, 1994 (436 páginas).

- En Honduras, de Marvin Barahona, Evolución histórica de la identidad nacional, Editorial Guaymuras, Tegucigalpa, 1993 (292 páginas).

- En Nicaragua, de Jorge Corominas y Judit Rivas, Identidad y pensamiento latinoamericano, Departamento de Filosofía, Universidad Centroamericana, Managua, 1992 (221 páginas). De Frances Kinloch Tijerino (editora), Nicaragua en busca de su identidad (texto en el que se han reunido y compilado 33 autores y escritos sobre el tema), Instituto de Historia de Nicaragua, Universidad Centroamericana, PNUD, 1995 (619 páginas). De Alejandro Serrano Caldera, La unidad en la diversidad. En busca de la nación, Managua, Ediciones Progreso, 1998.

- En Costa Rica, de Juan Rafael Quesada Camacho, América Latina: memoria e identidad 1492-1992, Editorial Respuesta, San José, 1993 (163 páginas). De Margarita Rojas (y otros tres autores), La casa paterna. Estructura y nación en Costa Rica, Colección Identidad Cultural, Editorial de la Universidad de Costa Rica, 1993 (361 páginas). De Arturo Taracena y Jean Piel (compiladores), Identidades nacionales y Estado moderno en Centroamérica (obra en la que se exponen 18 escritos de renombrados especialistas en el tema), Colección Istmo, Editorial de la Universidad de Costa Rica, 1995 (281 páginas). De María Salvadora Ortiz (compiladora), Identidades y producciones culturales en América Latina (libro en el cual se recogen 30 artículos de expertos en el tema), Colección Identidad Cultural, Editorial de la Universidad de Costa Rica, San José, 1996 (727 páginas). De la Escuela de Estudios Generales, Comunicación y Lenguaje de la Universidad de Costa Rica, Fronteras e identidades (dirigido a los estudiantes de Estudios Generales, donde se presentan 25 artículos de reconocidos autores latinoamericanos), Editorial de la Universidad de Costa Rica, 1998 (295 páginas). De Elíaz Zeledón Cartín (compilador), El santoral costarricense. Fiestas y tradiciones, Editorial de la Universidad de Costa Rica, San José, 1998 (427 páginas).

En El Salvador no existen libros como los arriba mencionados. En nuestro país, maestros, estudiantes y ciudadanos en general, preocupados e interesados en el tema y problema de la identidad nacional salvadoreña, no cuentan con un material bibliográfico pedagógico sobre este asunto, porque sencillamente no existe.

Más allá de los estudios científicos del psicólogo social Ignacio Martín-Baró, en El Salvador se ha investigado y escrito muy poco sobre identidad. No hay 
todavía nada sistemático y didáctico al respecto. Lo que existe está concentrado en un conjunto de artículos publicados en periódicos y revistas, y otros compilados en uno que otro libro que se ocupan del estudio de la cultura nacional de forma muy general ${ }^{30}$.

Mas, por otro lado, en el país se cuenta con varios textos, investigaciones y ensayos hechos desde distintas áreas de estudio en los que indirectamente se aborda la identidad nacional, pero cuya consulta resulta necesaria para quien quiera adentrarse a este tema y problema. Y sin pretender hacer una lista exhaustiva sobre los artículos y libros, escritos desde las primeras décadas del siglo y sobre todo después de la firma de los acuerdos de paz, se menciona una serie de obras que aparecen en el Anexo. Esbozo para una bibliografia identitaria salvadoreña, al final del artículo. En los textos que ahí se mencionan, se toca o alude de alguna forma u otra a la identidad nacional en sus múltiples dimensiones, por ejemplo antropológica, sociológica, lingüística, arquitectónica, folclórica, política, artística, económica, histórica, literaria, etc.

A continuación proporcionamos una breve presentación de la obra y persona de Martín-Baró. Primero porque su trabajo psico-social es de gran importancia para quien quiera adentrarse en el conocimiento de la identidad nacional salvadoreña y, segundo, porque este personaje de la historia nacional sigue siendo un modelo de profesional crítico y comprometido con la realidad salvadoreña y, por ello, un ejemplo digno de imitar y seguir.

\section{Herencia, vigencia y pasión de Ignacio Martín-Baró}

Martín-Baró es pionero en el estudio científico-social de la identidad nacional salvadoreña. Su psicología social es una obra científica y filosófica comprometida con la liberación de las sociedades latinoamericanas y, particularmente, con la liberación de El Salvador, su pueblo. En suma, la suya es una psicología liberadora de gran interés y actualidad internacional.

Nació el 7 de noviembre de 1942, en Valladolid, España, En ese mismo país entró a la Compañía de Jesús, en 1959 en Orduña. Llegó a El Salvador a principios de los años sesenta. Estudió filosofía en la Universidad Javeriana de Bogotá, teología en la Universidad de Lovaina, Bélgica, y en Frankfort, Alemania. Su formación en psicología la recibió en la UCA, San Salvador, donde obtuvo su licencia en 1975, y en Chicago, donde logró su maestría en 1977 y su doctorado en 1979.

Una psicología de la liberación, como indica uno de sus amigos y colegas, el psicólogo español Amalio Blanco, "es una apuesta contra la desmemoria; una apuesta escrita, además, desde la trágica experiencia de situaciones de injusticia estructural, violencia institucionalizada, desprecio a los derechos humanos, cruenta represión política y masiva expansión de la pobreza". Para él, asegura Blanco, "la liberación fue tanto una vivencia de la fe como una exigencia de la praxis 
psico-social"3ı. Y, en este contexto, estima que la propuesta de Martín-Baró se fundamenta en los siguientes principios:

- "Primacía de la realidad sobre los conceptos".

- “Esencial historicidad del ser humano".

- "Urgente necesidad de quebrar una estructura de creencias y valores que encadenan a la población al fatalismo".

- "Compromiso científico con el cambio de aquellas circunstancias que atentan contra la dignidad humana y el bienestar psicológico y social"32.

Por su parte, Maritza Montero señala que Martín-Baró fue el pionero de "una psicología de la liberación liberadora" y, al igual que Blanco, destaca el carácter histórico de su psicología social. Asimismo, sostiene que la propuesta fundamental que se evidencia en toda su obra es "hacer una práctica marcada por el lugar y por su gente", pues Martín-Baró fue "un psicólogo comprometido profunda y totalmente con su pueblo, con una sociedad y con una concepción de hacer ciencia desde una psicología que entendía como social y política, y con una labor liberadora hecha desde las personas y grupos necesitados de ella" ${ }^{33}$. Y entre las ideas principales que componen y orientan su psicología liberadora, Montero considera las siguientes:

En cuanto a la incorporación de las masas populares y su saber, Martín-Baró señalaba la necesidad de: (a) potenciar las virtudes populares; (b) el estudio de lo que llamaba los grupos con historia (Martín-Baró, 1988) ${ }^{34}$, es decir, organizaciones populares que debían ser estudiadas en su realidad, en su carácter histórico y en sus aspectos cualitativos, en función de tres dimensiones esenciales: su identidad, su poder y su actividad (1988, pp. 6-7); (c) el estudio sistemático de las formas de conciencia popular, respecto de la cual proponía la exploración de nuevas formas de expresión, y $(d)$ desideologizar el sentido común y la experiencia cotidiana, consciente como estaba de que también en ellos hallan asiento el error y la confusión, al lado de la crítica y la innovación.

En cuanto a la creación de una praxis psicológica transformadora liberadora: (a) desarrollar formas de control por parte de los grupos oprimidos. Lo que Fals Borda ha llamado autonomía del grupo (1959) ${ }^{35}$; (b) la desalienación social y personal; (c) superar el fatalismo existencial, tema sobre el cual publicó un agudo análisis ${ }^{36}, \mathrm{y}(d)$ estudiar el problema del poder.

En cuanto al rol de la psicología, para ella señalaba tres tareas: (a) Dedicarse a los problemas urgentes que plantean las sociedades latinoamericanas. Es decir, separarse de los problemas derivados de los libros y revistas científicos y atacar aquellos que sufre la gente. Recordemos que para los años ochenta, todavía había quien sostenía que la tarea de los psicólogos en nues- 
tros países debía ser replicar los estudios realizados en los centros académicos de Estados Unidos y Europa, a fin de demostrar si las hipótesis y las teorías creados en ellos eran o no aplicables en nuestro medio (Rodríguez, 1972) ${ }^{37}$. Algo que podríamos denominar como la propuesta de la zanahoria delante del asno. (b) Fomentar la recuperación de la memoria histórica en las mayorías oprimidas, lo cual contribuirá a la desalienación y desideologización.

(c) Los psicólogos deben comprometerse con la transformación social que libere a los oprimidos de las condiciones que les oprimen ${ }^{34}$.

Al abordar directamente la obra de Martín-Baró, encontramos en su artículo El papel desenmascarador del psicólogo, que data de 1985, que "la conciencia no es simplemente el ámbito privado del saber y sentir subjetivo de los individuos, sino sobre todo aquel ámbito donde cada persona encuentra el impacto reflejo de su ser y de su hacer en sociedad, donde asume y elabora un saber sobre sí mismo y sobre la realidad que le permite ser alguien, tener una identidad personal y social". La conciencia, así entendida, "es una realidad psico-social relacionada con la conciencia colectiva"39.

Para Martín-Baró, era importante que las personas asumieran su propio destino, tomando ellos mismos las riendas de su vida, pero para lograr esto se "les exige superar su falsa conciencia y lograr un saber crítico sobre sí mismos, sobre su mundo y sobre su inserción en ese mundo". Es decir, se necesita que pasen por "un proceso de concientización" que supone tres aspectos:

El ser humano se transforma al ir cambiando su realidad. Se trata, por consiguiente, de un proceso dialéctico, un proceso activo que, pedagógicamente, no puede darse a través de la imposición, sino sólo del diálogo.

Mediante la paulatina descodificación de su mundo, la persona capta los mecanismos que la oprimen y deshumanizan, con lo que se derrumba la conciencia que mitifica esa situación como natural y se le abre el horizonte a nuevas posibilidades de acción. Esta conciencia crítica ante la realidad circundante y ante los demás arrastra por tanto la posibilidad de una nueva praxis, que a su vez posibilita nuevas formas de conciencia.

El nuevo saber de la persona sobre su realidad circundante le lleva a un nuevo saber sobre sí misma y sobre su identidad social. La persona empieza a descubrirse en su dominio sobre la naturaleza, en su acción transformadora de las cosas, en su papel activo en las relaciones con los demás. Todo ello le permite no sólo descubrir las raíces de lo que es, sino el horizonte de lo que puede llegar a ser. Así, la recuperación de su memoria histórica of rece la base para una determinación más autónoma de su futuro ${ }^{41}$.

Consideraba la concientización como un horizonte esencial para el quehacer psicológico. Por eso sostiene en ese mismo texto, que "al asumir la concientización como horizonte del quehacer psicológico, se recoge el necesario centramiento de 
la psicología en el ámbito de lo personal, pero no como terreno opuesto o ajeno a lo social, sino como correlato dialéctico y, por tanto, incomprensible sin su referencia constitutiva. No hay persona sin familia, aprendizaje sin cultura, locura sin orden social; por tanto no puede haber un yo $\sin$ un nosotros, un saber $\sin$ un sistema simbólico, un trastorno que no remita a unas normas morales y a una normalidad social"4l.

A su juicio, "la concientización obliga a la psicología a dar respuesta a los grandes problemas de injusticia estructural, de guerra y de enajenación nacional que agobian a estos pueblos. No se puede hacer psicología hoy en Centroamérica sin asumir una seria responsabilidad histórica; es decir, sin intentar contribuir a cambiar todas aquellas condiciones que mantienen deshumanizadas a las mayorías populares, enajenando su conciencia y bloqueando el desarrollo de su identidad histórica..." ${ }^{\text {"2 }}$.

Y si sostenía, por tanto, que en su quehacer científico el psicólogo social debe asumir la concientización como horizonte de su praxis, era porque tal afirmación la fundamentaba en tres grandes razones:

En primer lugar, porque la concientización responde a la situación de injusticia promoviendo una conciencia crítica sobre las raíces, objetivas y subjetivas, de la enajenación social. Una simple conciencia sobre la realidad no supone por sí misma el cambio de esa realidad; pero difícilmente se arremeterá con los cambios necesarios mientras todo un velo de justificaciones, racionalizaciones y mitos encubran los determinismos últimos de la situación de los pueblos centroamericanos. La concientización no sólo posibilita, sino que puede incluso desencadenar el cambio, el romper con los esquemas fatalistas que sostienen ideológicamente la alienación de las mayorías populares.

En segundo lugar, el proceso mismo de la concientización supone el salirse de la mecánica reproductora de las relaciones de dominación-sumisión, ya que sólo puede realizarse a través del diálogo....

Finalmente, la toma de conciencia apunta directamente al problema de la identidad tanto personal como social, grupal y nacional. La concientización lleva a las personas a recuperar la memoria histórica, a asumir lo más auténtico de su pasado, a depurar lo más genuino de su presente y a proyectar todo ello en un proyecto personal y nacional...43. 1,

El interés por la historicidad del ser humano, la preocupación por la concientización, la lucha contra la alienación, el fatalismo y la injusticia estructural, así como el trabajo por la recuperación de la memoria histórica llevaron a Martín-Baró a estudiar el fenómeno socio-cultural e histórico de la identidad personal, social y cultural desde y para la realidad salvadoreña y latinoamericana. $Y$ para quien desee volcarse al análisis de la identidad en El Salvador, sea a partir de la psicología social, la filosofía, la sociología, la antropología o con cualquier 
otro saber, su trabajo intelectual constituye una obra de referencia obligada por las inapreciables investigaciones que llevó a cabo en este campo y, sobre todo, por las duras y peligrosas condiciones en que le tocó realizarlas y, aún así, compartirlas y hacerlas del conocimiento público nacional e internacional ${ }^{44}$.

En un país como el nuestro bien vale la pena detenerse a reflexionar unos instantes respecto a esto último, es decir sobre el trabajo y sacrificio intelectual y religioso que llevó a cabo Martín-Baró, y por los cuales perdió su vida, ya que en El Salvador la historia no sólo se ignora sino que se desprecia, por lo cual los acontecimientos más recientes resultan tan fáciles de olvidar o son totalmente desconocidos y por ello los errores y horrores históricos cometidos en el pasado más cercano o lejano son tan proclives a repetirse en nuestra sociedad. $Y$ hacer esto es fundamental para ocuparse del estudio de la identidad nacional, ya que no hay identidad nacional presente y consciente sin memoria y conocimiento de los elementos, personajes y circunstancias históricos que la han determinado y posibilitado. Asimismo, hacerlo nos permite encontrar en el recuerdo de la persona y en el estudio del legado intelectual de Martín-Baró, un ejemplo de amor y esperanza para los salvadoreños y latinoamericanos de hoy. Porque, como bien ha dicho el teólogo de la liberación Jon Sobrino, "en este mundo, en efecto, trivializado y gris, sin utopías ni ilusiones, es importante encontrar personas que, por su modo de ser, comuniquen luz y ánimo para que podamos ser humanos y

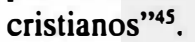

Rememoremos, entonces, aquellas frases suyas expuestas en su libro Acción e ideología. Psicología social desde Centroamérica, publicado en 1983, cuyas palabras todavía continúan transmitiendo luz y ánimo, e invitándonos a ser más humanos y cristianos en nuestra actual sociedad. Una obra escrita durante los años más conflictivos y sangrientos de la guerra civil salvadoreña, y en la que, en su prólogo, Martín-Baró expone:

Como científico social no es fácil vivir desde dentro un proceso tan convulso. Y no lo es por muchas razones, extrínsecas unas, intrínsecas otras. La dificultad más obvia proviene del riesgo que corre la vida de quienes pretenden iluminar los problemas que están a la raíz del conflicto o contribuir a la búsqueda de su solución. No interesa conocer la realidad, cuando esa realidad es tan expresiva, tan clara en su sentido, que el sólo hecho de nombrarla con verdad constituye un acto "subversivo". Si, el llamar a la realidad por su propio nombre convirtió a Monseñor Romero en profeta para su pueblo, en voz de los sin voz, le convirtió también en revolucionario y subversivo para el poder establecido. A los tres días de su patético llamado a los cuerpos policiales, "en nombre de Dios, ¡cese la represión!", era asesinado mientras celebraba la eucaristía ${ }^{4 h}$.

Martín-Baró también sufrió una pasión y muerte parecida a la de Monseñor Romero, por referirse, asimismo, a la realidad histórica y cultural salvadoreña de 
los años ochenta, desde sus investigaciones científico-sociales y desde sus prédicas religiosas, por su propio nombre. Pues, como sacerdote comprometido y como psicólogo social crítico, tomó siempre en cuenta en sus investigaciones y sermones la realidad nacional en sus distintas dimensiones: social, política, económica, cultural e histórica, las cuales, sabía muy bien, no sólo condicionan sino estigmatizan al ser salvadoreño. Le pesaba esa realidad "caracterizada por la injusticia estructural y la violencia institucionalizada, por la dependencia internacional y por la polarización social"47 en que vivía. Por eso, desde el púlpito de su parroquia en Jayaque o desde la UCA con sus investigaciones y cátedras, denunció y combatió siempre de manera espiritual y académica la represión, la opresión, la injusticia, la tortura, las desapariciones, los asesinatos, la corrupción, la ausencia de derechos humanos, la mentira institucionalizada, el machismo, la pobreza y miseria que identificaban y nominaban en ese entonces a la sociedad salvadoreña. Por consiguiente, como a Monseñor Romero, los detentores del poder económico, político y militar establecido en esos años ochenta lo acusaron de "subversivo", "revolucionario" y "comunista", junto a muchos otros laicos y religiosos. Y su nombre figuró en la "lista negra" de los mal llamados "cuerpos de seguridad nacional", representantes directos en esos días del terrorismo de Estado... Hasta que, finalmente, se ordenó su asesinato. Esto fue durante la inesperada "ofensiva hasta el tope" que llevaba a cabo el FMLN en el mes de noviembre de 1989, bajo el pretexto y convencimiento que sus adversarios -la Fuerza Armada y el gobierno dirigido por el partido ARENA - sólo hacían caso a "la presión de la fuerza"; no obstante, la ofensiva fue seriamente criticada por varios sectores por "usar a la población civil como escudo" y crear junto al ejército más terror, destrucción y muerte en la población civil y poner en peligro el diálogo en curso por la paz $^{48}$... Sí, pero a pesar de las críticas, la ofensiva guerrillera fue muy bien aprovechada por varios elementos del gobierno, de la oligarquía y del ejército para eliminar a sus opositores más críticos y temidos de la UCA: su rector y filósofo Ignacio Ellacuría, el sociólogo Segundo Montes y el psicólogo social Ignacio Martín-Baró. Los tres fueron ejecutados junto a sus hermanos jesuitas Juan Ramón Moreno, Amando Lopéz y Joaquín López y López, al lado de Elba y Celina Ramos, dos humildes mujeres que trabajaban en la universidad, y asesinados los ocho de la manera más cobarde y bestial por un escuadrón de "obedientes" oficiales y soldados del batallón Atlacatl. Y no olvidemos que esta masacre sucedió jhace apenas diez años en este país! Sí, la madrugada del 16 de noviembre de 1989, en las instalaciones de la UCA... Y si bien es cierto que se enjuició a los hechores del crimen -más por la presión internacional que por una sincera aplicación de la justicia nacional-, a los que planearon y ordenaron sus muertes en cambio no se les conoce, al menos públicamente, y aún siguen libres e impunes por ahí, pero seguramente con sus conciencias intranquilas por haber segado y truncado estas vidas tan profundamente humanas y cultural e intelectualmente productivas. 
Esta historia infame y sangrienta de las últimas décadas, en la que los practicantes de la irracionalidad, la brutalidad y la intolerancia - tan comunes en un bando como en el otro, antes y durante la guerra civil-, eliminaron a personas y personajes como Monseñor Romero, Ignacio Ellacuría y, antes que ellos, a Roque Dalton ${ }^{49}$, ha conducido a Francisco Andrés Escobar a plantearnos, a todos los salvadoreños, la pregunta: " ¿A dónde irá un país que ha asesinado a su profeta, a su filósofo y a su poeta?".

Martín-Baró nunca se interesó, pues, por "el individuo como tal, sino en cuanto es miembro de un sistema social"sil. La postura por excelencia que siempre asumió fue "la de la historicidad del comportamiento humano"s!. Y para él era evidente que "el problema más importante que confrontan las grandes mayorías latinoamericanas es su situación de miseria opresiva, su condición de dependencia marginante que les impone una existencia inhumana y les arrebata su capacidad para definir su vida"s2.

La triste situación que él denunciaba en 1986, en su artículo Hacia una Psicología de la liberación, es hoy, al final de los años noventa, una realidad aún no superada en gran medida en la mayoría de países latinoamericanos, debido a la injusticia estructural y a la dependencia internacional. Porque, no obstante el fin de casi todos los conflictos armados - con excepción de Colombia y México-, la instauración de procesos y acuerdos de pacificación, y el nacimiento e incipiente ejercicio de la democracia en casi todas las naciones latinoamericanas, la "situación de miseria opresiva" y la "condición de dependencia marginante" siguen siendo todavía una situación que no sólo impone a las grandes mayorías populares de nuestros países una existencia inhumana sino que, al mismo tiempo, les continúa arrebatando la capacidad de asumir y planificar una mejor vida futura colectiva. En otros términos, la "situación de miseria opresiva" y la "condición de dependencia marginante" nos impiden crear y poner en práctica verdaderos y sostenibles "planes de nación" para el desarrollo de nuestras realidades e identidades culturales e históricas, tanto locales, nacionales y regionales en América Latina.

\section{Martín-Baró y sus investigaciones psico-sociales sobre la identidad}

Enumeramos a continuación algunos de los principales estudios que MartínBaró realizó y publicó, relacionados con la identidad nacional salvadoreña. La lista que se presenta es sólo una aproximación a su producción teórica, una obra que constituye, sin duda, uno de los más valiosos materiales científicos que en el país se han realizado sobre este tema y problema, antes y durante los años ochenta. Expuestos en orden cronológico, los artículos y libros que se mencionan y recomiendan son:

(1968) "El comple jo de macho o el machismo", Estudios Centroamericanos (ECA), 235, 1968, pp. 38-42. 
(1972) "Presupuestos psicosociales de una caracteriología para nuestros países", ECA, 290, 1972, pp. 765-786. Reeditado en Psicología de la liberación, Madrid, Editorial Trotta, 1998, pp. 39-71.

(1980) “La imagen de la mujer en El Salvador", ECA, 380, 1980, pp. 557-568.

(1983) Acción e ideología. Psicología social desde Centroamérica (I), San Salvador, UCA Editores, 1983.

(1983) "Los rasgos femeninos según la cultura dominante en El Salvador", Boletín de Psicología, 8, 1983, pp. 3-7.

(1986) “La ideología familiar en El Salvador", ECA, 450, 1986, pp. 291-304.

(1985) "El papel desenmascarador del psicólogo". En Psicología de la liberación, op. cit., pp. 161-199.

(1987) “¿Es machista el salvadoreño?”, San Salvador, Boletín de Psicología, 19, 1987, pp. 5-20.

(1987) "Realidad psicosocial del latinoamericano: presente y futuro". Ponencia presentada en el XXI Congreso Interamericano de Psicología, La Habana, julio de 1987.

(1987) "El latino indolente". En Psicología política latinoamericana, texto coordinado por Maritza Montero, Caracas, Universidad Central de Venezuela, 1987. Reeditado en Psicología de la liberación, op. cit., 1998, pp. 73-101.

(1987) “La identidad nacional del salvadoreño", San Salvador, Departamento de Psicología y Educación, Universidad Centroamericana "José Simeón Cañas", 1987 (manuscrito inédito).

(1987) Así piensan los salvadoreños urbanos (1986-1987), San Salvador, Instituto Universitario de Opinión Pública, UCA Editores, 1987.

(1989) Sistema, grupo y poder. Psicología social desde Centroamérica (II), San Salvador, UCA Editores, 1989.

(1989) La opinión pública salvadoreña (1987-1988), San Salvador, Instituto Universitario de Opinión Pública, UCA Editores, 1989.

(1990) “ ¿Trabajador alegre o trabajador explotado? La identidad nacional del salvadoreño", Revista de Psicología de El Salvador, 37, 1990, pp. 147-172. Reeditado en Psicología de la liberación, op. cit., pp. 103-128.

(1990) Psicología social de la guerra, San Salvador, UCA Editores, 1990. Libro colectivo cuya introducción y selección de textos estuvo a cargo de Martín-Baró, y en el que figuran sus siguientes artículos: "Guerra y salud mental", "La violencia política y la guerra como 
causas del trauma psicosocial en El Salvador", "De la guerra sucia a la guerra psicológica: el caso de El Salvador", "Guerra y trauma psicosocial del niño salvadoreño".

(1998) Psicología de la liberación (cuya edición, introducción y notas fueron realizadas por Amalio Blanco), Madrid, Editorial Trotta, 1998.

En los próximos artículos se espera presentar una visión de conjunto de la obra de Martín-Baró, comparándola con la de otros investigadores y especialistas en el tema y problema de las identidades nacionales. Principalmente se estudiarán las raíces y la adquisición de la identidad individual y colectiva, como también sus trabajos en cuanto al delicado y discutido tema de la identidad salvadoreña y de la identidad regional latinoamericana. Sin embargo, adelantemos una idea más sobre la identidad nacional en el siguiente punto.

\section{Una idea sobre la identidad nacional en Martín-Baró}

Martín-Baró muestra que la llamada identidad nacional estaría compuesta por factores tanto objetivos como subjetivos. Los objetivos serían aquellas características propias de un grupo, o de una serie de grupos, en un determinado país, como por ejemplo: el entorno natural y espacial, la lengua, las raíces raciales comunes, las tradiciones, costumbres, etc. Mientras los factores subjetivos serían aquellos que propiciarían "el que las personas asumieran como propia la identidad nacional" y que, además, posibilitarían que se sintieran parte de esa comunidad. Los factores subjetivos, pues, se refieren "a la conciencia de la identidad nacional, es decir, a la percepción más o menos clara del grupo como nación y de uno mismo como perteneciente a ese grupo; pero está, también, la aceptación normativa, más o menos voluntaria, de sus valores, normas y estílos de vida. La identidad nacional surgiría, por tanto, del hecho de compartir unas condiciones objetivas de vida, y se materializaría mediante la conciencia refleja y operante de las personas involucradas"s?.

Ahora bien, añade que "el que existan unas condiciones objetivas comunes no es sin más suficiente para que se dé una identidad nacional". Y refiriéndose a las repúblicas centroamericanas, afirma que "es claro, por ejemplo, que existen poblaciones con características muy similares que habitan en un mismo entorno natural y comparten una historia fundamentalmente común y que, sin embargo, se encuentran divididas no sólo por las fronteras políticas de los países, sino por la asunción de identidades nacionales diferentes y hasta expresamente contrapuestas". Por esta razón, sostiene que "no hay, por tanto, un paso automático de las condiciones objetivas a la conciencia subjetiva de identidad, y menos aún a la asunción consciente de esa identidad nacional"\$4.

Basándose en otros autores y estudios científicos sobre este fenómeno sociocultural, expone que "la identidad nacional arranca de la unidad étnico-cultural 
de un grupo, pero se desarrolla mediante los esfuerzos deliberados por ideologizar esas características comunes y por movilizar a las personas a partir de ellas". Por consiguiente, su idea es que la identidad nacional es el resultado de una combinación de realidades históricas y de movilizaciones nacionalistas deliberadas, estimuladas, estas últimas, "por quienes tienen el poder en cada país para beneficio de sus intereses de clase"s5.

Ahora, cuando la población de un determinado país carece de identidad, esto puede deberse, según él, "a que falten las condiciones objetivas como a que no se ha realizado una ideologización de esas condiciones" 56 .

Pero también se puede producir en país determinado una identidad nacional cuyas condiciones objetivas no son realmente comunes a todos los sectores de la población, o que son percibidas distorsionadamente en su carácter común, lo cual, va "en beneficio de los intereses de quienes detentan el poder social y producen la movilización nacionalista". Y, en su opinión, "este podría ser uno de los problemas psico-sociales de algunas poblaciones latinoamericanas y, en concreto, de la salvadoreña"s7.

No obstante, afima que "resultaría simplista considerar que la mayoría de personas asumen una identidad con frecuencia tan profunda y vinculante como la identidad nacional simplemente como efecto de una manipulación social. $\mathrm{Si}$ así fuera, esa identidad tendería a desaparecer tan pronto se alteraran esas condiciones objetivas de dependencia social. Pero como lo muestra la experiencia de muchos emigrantes o de grupos emancipados, eso no es así. Por tanto, parece razonable pensar que, sin ignorar lo que de manipulación ideológica hay en la identidad nacional, su desarrollo personal se asienta en significaciones más particulares, en representaciones muy limitadas pero que adquieren carácter nacional". En otros términos significa que "las personas no se sienten salvadoreñas por identificarse con la totalidad de la población de El Salvador (que, obviamente no conocen) ni por recibir como propia la historia del país (que con frecuencia, incluso la ignoran), sino por asumir como la identidad de El Salvador las representaciones vinculantes de su grupo social (su familia, sus amigos y vecinos), su particular entorno natural, sus costumbres y estilo de vida". Y si esto es así, dice, "tras las imágenes expresas de la identidad nacional habrá que descubrir el referente concreto de cada grupo para deslindar lo que de común y lo que de diferencial hay en ellas"ss.

Hemos presentado someramente algunos elementos fundamentales sobre los estudios realizados por Martín-Baró en relación a la identidad nacional. La pregunta que puede hacerse el lector, después de todo lo anterior, es si hay o no otras investigaciones, y especialmente desde otras áreas de estudio sobre nuestro ser colectivo nacional. La respuesta es no. Porque además de los contados artículos y ensayos enumerados en la lista expuesta en el Anexo. Esbozo para una bibliografía identitaria salvadoreña, no parece haber en el país realmente otros estu- 
dios científicos y filosóficos tan sistemáticos y concretos como los de MartínBaró. Veamos a continuación algunas razones sobre porqué se ha dado y se continúa dando esta situación de pobreza intelectual en El Salvador.

\section{Problemas para el estudio y conocimiento de la identidad nacional}

No se menciona en el Anexo. Esbozo para una bibliografia identitaria salvadoreña, por supuesto, a todos los teóricos e investigadores que han escrito, indirecta o directamente, sobre la identidad nacional salvadoreña. Hace falta hacer una investigación exhaustiva sobre un índice de obras nacionales; mas éste no era ni es nuestro propósito. Lo que pretendemos con esas nóminas dadas es proporcionar al lector una bibliografía identitaria nacional elemental que le muestre el nivel en que se encuentra el estudio de la identidad en nuestro país, y que además le ayude y oriente a introducirse y profundizar en esta temática y problemática por medio de una serie de obras relacionadas con nuestra identidad.

Pero la bibliografía expuesta sobre lo nacional es realmente insuficiente. Insuficiente para lo mucho que puede y pudiera decirse y escribirse sobre nuestra realidad e identidad histórica y cultural. Pues la mayoría de los textos que se nombran sólo se ocupan de manera indirecta sobre la identidad nacional; aunque todos los artículos y libros nombrados sean importantes y algunos esenciales para la investigación y comprensión de la misma.

En otro sentido, es necesario subrayar que varios de los autores de estos artículos y libros son personas extranjeras, identificadas intelectual y sentimentalmente con la realidad del país, y con quienes los salvadoreños estaremos siempre en deuda por su labor académica en favor de nuestro desarrollo cultural. $\mathrm{Y}$ si decimos y remarcamos esto es porque, aunque resulte penoso decirlo, en El Salvador hay muy poca producción teórica en el campo de las ciencias humanas y sociales, y gran parte de lo que tenemos se lo debemos a instituciones e investigadores extranjeros que han realizado y financiado tales estudios. ¿Las razones? Pueden darse dos: porque hace falta más y mayor preparación académica y metodológica para la investigación en las universidades y porque no hay apoyo a la creatividad y producción intelectual e investigativa de los especialistás y profesionales que tiene país. Detengámonos en la última justificación.

No abundan pero en El Salvador existen buenos y excelentes científicos y filósofos sociales con muchos deseos de investigar, pero no hay ayuda ni interés gubernamental ni privado para financiar sus proyectos de investigación en el campo de la antropología, la arqueología, la psicología social, la historia, la sociología, la lingüística, la filosofía, etc. Esto es un problema muy grave y serio para un real y verdadero conocimiento, conciencia y valoración de la identidad nacional. Sin embargo se han gastado fortunas millonarias en los últimos años en la edición y publicación de bellísimos pero costosísimos libros que sólo están al alcance de las élites y cuyos contenidos son más fotográficos que teórico- 
científicos, destinados quizás más bien a la promoción turística del país o tal vez a los coffee break de la alta sociedad; mas no a la educación de la juventud y del pueblo en general, porque estos en su mayoría o no saben de su existencia o se conforman sólo con verlos en los estantes de las contadas librerías del país ${ }^{54}$. Al menos estos libros tan caros deberían donarse a las no menos contadas bibliotecas públicas o a las casas de la cultura del país para que la gente los admire y lea.

A este propósito, el historiador mexicano Mario Vázquez ha expuesto, refiriéndose al cultivo de la historia en El Salvador, una crítica muy certera que bien podemos generalizar, en algunos aspectos, a muchas otras áreas de las ciencias humanas y sociales, pues la falta de estudios e investigaciones históricas es una de las grandes causas por las que en el país no existe conocimiento ni conciencia de la identidad nacional:

Dentro del contexto centroamericano, a pesar de la reconocida importancia que ha tenido en la región el cultivo de esta disciplina, llama la atención el caso particular de El Salvador, donde hasta la fecha parece primar un peculiar desdén por la investigación, la escritura y la difusión de la historia. Nunca existió en el país la carrera de Historia a nivel universitario, y son contados los salvadoreños que han optado por estudiarla en el extranjero. Por si fuera poco, a falta de un adecuado respaldo institucional, los historiadores locales se han visto obligados a desarrollar su trabajo de manera particular, sorteando numerosos obstáculos para llevar a cabo sus investigaciones y alcanzar a publicar cuando menos una parte de su obra. Como resultado, en El Salvador existe apenas una débil tradición historiográfica. Desde luego, intentar explicar este fenómeno, que podría ser señalado inclusive como un rasgo peculiar de la cultura nacional de este país, nos remitiría a un estudio detallado del proceso de conformación del estado salvadoreño y su relación con el desenvolvimiento intelectual, a partir, por lo menos, de mediados del siglo pasado. Difícil tarea que tarde o temprano deberán emprender los estudiosos salvadoreños..."

Por su lado, el filósofo y mártir Ignacio Ellacuría, quien se ocupó de la dimensión política de la identidad nacional, al referirse a uno de los rasgos que caracterizan al ser salvadoreño, expresó: "La memoria histórica es bien corta en El Salvador. Por eso no se acumula experiencia ni tradición"

El desprecio por la historia en El Salvador también era evidente para el filósofo, y hay que destacar que esa corta memoria histórica que él denunció es otra de las causas por las que en la población salvadoreña no existe una identidad nacional consciente y mucho menos crítica. Es necesario crearla. Es esencial trabajar en su construcción. Un trabajo en el cual la historia, es decir su estudio y conocimiento, tiene un papel fundamental a desempeñar, evidentemente al lado de la filosofía y demás ciencias humanas y sociales, para la creación y 
desarrollo de una identidad nacional consciente, crítica y con bases reales en la diversidad de elementos culturales y grupos sociales nacionales.

La historiadora española María Carmen García-Nieto París sostenía, tras su visita al país luego de la firma de los acuerdos de paz, que "El Salvador se encuentra en una de las coyunturas más interesantes y esperanżadoras de su historia. La historia es el arma que nos permite recuperar el conocimiento de la realidad nacional salvadoreña reciente y actual, en momento de cambio, a través de un proceso de transición y construcción de la democracia"

Pero pese a todo esto los salvadoreños no caemos en la cuenta de lo importante que es el conocimiento y conciencia de nuestra verdadera historia nacional y regional para "cambiar las condiciones que deshumanizan y enajenan nuestra conciencia bloqueando el desarrollo de nuestra identidad cultural e histórica actual". Pues, un proceso de cambio no es eterno. Si en la transición no hay cambios, lo que hay es estancamiento y hasta retroceso. Los años pasan y las oportunidades de transformación social y cultural se nos escapan como espuma entre las manos, mientras la desmemoria y la ignorancia crecen y aumentan, sumiendo cada vez más a los salvadoreños en una profunda inconsciencia identitaria. Y el desdén por la historia continuará siendo "un rasgo peculiar de la cultura nacional", la memoria histórica se irá acortando cada vez más y no acumularemos "experiencia ni tradición", por lo que estaremos condenados a repetir los erro-, res y horrores del pasado reciente y profundo que marcan la historia de nuestro país y de nuestra gente.

Por lo visto seguimos siendo, como dice David Escobar Galindo, "un país que se niega a recordar". Pero esperanzado, el poeta anima a retomar "el hilo de las herencias". Y animando a los salvadoreños, dice: "Hay que darle cuerpo a las genealogías, personales y colectivas. La labor es de voluntad y de rescate... Ha pasado el tiempo del mal olvido. Vamos entrando al tiempo del buen recuerdo. Pero esto no se dará como proyecto espontáneo. La memoria no crecerá como crecen las enredaderas. Hay que organizar la transición entre el olvido y la memoria. El país, que se ha negado tan fervorosamente a recordar, tiene que aprender ese arte necesario, sin el cual todos los sufrimientos vuelan en cenizas, todas las conquistas descansan en parajes quebradizos" $\$$.

Sí, la historia es el arma o, mejor dicho, una de las armas para identificarse con el país y asumir y reivindicar una verdadera identidad nacional. La recuperación de la historia es uno de los criterios fundamentales para la creación de una identidad nacional consciente y crítica en los salvadoreños. Pues, como ha dicho el antropólogo mexicano Guillermo Bonfil Batalla, "todos los problemas importantes hallan solución con el conocimiento de la historia", porque "sin historia no se es y con una historia falsa, ajena, se es otro pero no uno mismo"th.

"Un pueblo que no ama su pasado es un pueblo sin conciencia, sin sentido y, sobre todo, es presa fácil de sus enemigos", afirmaba el escritor y poeta guate- 
malteco Miguel Ángel Asturias. "Sin una tradición detrás los latinoamericanos no podremos crear nada nuevo", asegura por su parte el novelista y ensayista mexicano Carlos Fuentes.

Pues la identidad nacional "como síntesis y producto de procesos históricos dados, no puede ser explicada sin recurrir al pasado de la sociedad que es portadora de esa identidad"'ss, nos dice el historiador hondureño Marvin Barahona.

Por estas razones también Ellacuría decía: "Hay que volver a buscar las raíces, unas raíces que hay que redescubrir porque siguen hundidas y vivas en la tierra nutricia de nuestros pueblos y son las que posibilitarán futuros inéditos, que no pueden ni siquiera soñarse porque tienen aún que brotar".

\section{La identidad nacional en las políticas culturales gubernamentales}

No se conoce de ningún plan gubernamental para el conocimiento, educación, valoración, difusión, fortalecimiento y desarrollo de la identidad cultural e histórica nacional. Se han hecho y hacen esfuerzos aislados en nombre de la "cultura nacional", pero que fácilmente se pierden en el olvido, por muy importantes que sean. Estos esfuerzos tienen su origen en el Ministerio de Educación, CONCULTURA y la Dirección General de Publicaciones, no obstante, la mayoría de las veces estas instituciones cometen el error de manejar y propagar una idea muy estrecha del concepto cultura $^{\text {th }}$ - limitándolo exclusivamente al arte, la pintura, la música y la literatura-, por lo que en ellas predomina una visión muy parcial de la identidad salvadoreña. Mas no se conoce una estrategia sistemática y metódica, con fines educativos y didácticos, que se ocupe globalmente del tema y problema de la identidad nacional. Sin embargo, Bases para el plan de nación podría ser un buen punto de partida.

En el documento Bases para el plan de nación ${ }^{67}$ es clara la preocupación por crear una nueva cultura de responsabilidad, productividad, solidaridad, tolerancia, humanismo y respeto a las leyes. Se concibe el desarrollo "como un proceso participativo que debe incluir de manera armónica factores económicos, territoriales, ambientales, políticos, éticos, sociales y culturales". Se habla de la necesidad de una manifestación de la conciencia nacional, de un "dinamismo participativo" y de una "voluntad de compromiso social": "imprescindibles para lograr el desarrollo integral de El Salvador". Se está consciente de que El Salvador "está inmerso en un proceso de transición que tiene como punto de partida el Acuerdo de Paz y como meta histórica la plena democratización del país", y que en tal transición nacional se requiere de recomposiciones y acciones en el nivel político, en el cultural educativo, en el socioeconómico, en el de la participación ciudadana y en el institucional del Estado, "para lograr que la sociedad vaya reconociendo su auténtica y profunda realidad, a modo de avanzar de manera cada vez más consistente hacia la sociedad integrada que es el único escenario posible de la estabilidad, la paz y el desarrollo". Se dice muy enfáticamen- 
te que en este proceso de transición, en sus diferentes niveles, se debe "tomar plena conciencia nacional de que el proceso es un todo, porque el país es un todo y porque el destino nacional es un todo", por lo que se debe "asumir el proceso como un proyecto compartido por todos los sectores y fuerzas nacionales, sin cuyo concurso nunca saldremos de la fragmentación y la improvisación" "sb.

En fin, entre muchas otras cosas, se afirma que "tenemos que hacer de El Salvador un país de todos y para todos, donde se potencie nuestra laboriosidad en función de una visión común y positiva de nuestro destino", donde "la juventud encuentre nuevos vínculos de pertenencia". Pues, "la identidad cultural implica condiciones de inclusión, participación y contribución a un proyecto común". Por tanto, "debemos evitar ser un país que sea percibido por muchos salvadoreños como un espacio provisional, donde la gente no asume un real compromiso de destino común". Como también, "debemos fortalecer las condiciones que permitan desarrollar la confianza, desplegar la solidaridad y arraigar el sentimiento de pertenencia nacional"

Por otra parte, el actual presidente de la República, Francisco Flores, en su recién pasada campaña electoral, al presentar su oferta cultural, en Santiago Texacuangos, San Salvador, manifestó que "la cultura es desarrollo para el país". Expresó que "los salvadoreños estamos heridos de la memoria", y además dijo (según escribe el redactor de la noticia) que "nunca en la historia del país se ha planteado el tema cultural", por lo que es necesario (palabras textuales del propio presidente): "rescatar la identidad nacional"70.

Analicemos las Bases para el plan de nación. Este manifiesto no parte de un diagnóstico sobre la realidad y la identidad cultural e histórica nacional. "No dice que ya estemos bien sino que quisiéramos estar bien"'1. En él se dice lo que El Salvador debe o debería ser. Sin embargo, una lectura de este documento hecha al revés muestra lo que el país es, o sea su realidad presente y actual. Sí, al igual que el tan sonado y repetido concepto desarrollo humano sostenible, el documento en cuestión es también un discurso eufemístico y sobre todo una ideologización de la realidad —n la que sus autores caen aunque quizá no intencionalmente-, pues en el fondo, cuando se habla de desarrollo humano sostenible, se está diciendo que el desarrollo occidental mundial actual no es ni humano ni sostenible en ningún país del planeta"2; asimismo, en las Bases para el plan de nación, al decir lo que El Salvador quiere ser o debe llegar ser, se oculta y deforma lo que el país realmente es.

Entonces, ¿qué se oculta y deforma -intencionalmente o no- en el texto Bases para el plan de nación? Pues la verdadera realidad e identidad salvadoreña, ya que en este documento se encubre lo que en gran parte somos los salvadoreños. Sí, dándole vuelta a este discurso entresacamos que los salvadoreños somos en gran medida una nación sin responsabilidad, sin productividad, sin solidaridad, sin tolerancia, sin integración, sin planificación, sin humanismo y 
sin respeto a las leyes como podríamos serlo. Se contralee que somos un país con un desarrollo que no es participativo y que no incluye de manera armónica factores económicos, territoriales, ambientales, políticos, éticos, sociales y culturales. Una sociedad donde la conciencia nacional no se manifiesta. Una república en la que no existe un dinamismo participativo y tampoco una voluntad de compromiso social. Una nación en la que está lejos pero muy lejos la "meta histórica" de lograr la plena democratización del país si no llevamos también la transición democrática, además del campo político, al terreno social, económico y cultural. Un país sin estabilidad, paz y desarrollo social y económico. Una sociedad en la que no existe unidad de su rica y valiosa diversidad socio-cultural por lo que se carece de una plena y armoniosa integración de todas sus partes en la vida nacional. Una república sumida en la "fragmentación" y la_ "improvisación", y en la que unas partes, clases o grupos privilegiados no trabajan en función del "todo" social y cultural nacional, sino en provecho de sus propios y mezquinos intereses y beneficios. Una sociedad sin verdaderos vínculos y sentimientos de pertenencia al territorio, las tradiciones y el patrimonio cultural, por lo cual todo termina siempre, como popularmente se dice, "valiendo v...". Un país donde la mayoría de sus ciudadanos viene arrastrando una vieja mentalidad colectiva de siglos, heredada por los españoles conquistadores, y que consiste en seguir viendo y viviendo el país como un botín en lugar de verlo y vivirlo como bien común o "república", es decir como una "cosa de todos". Una nación que ha dejado de ser "suelo" nutricio donde echar raíces y que cada día que pasa la estamos volviendo cada vez más "un piso"73 o espacio pavimentado para ir y venir pero menos para residir y vivir. Una república donde gran parte de sus ciudadanos desea emigrar por falta de seguridad y estabilidad nacional y toma al país como algo provisional. Una comunidad sin comunión ni solidaridad en la que nos encontramos forzados y resignados a vivir unos junto a otros, en lugar de unos con otros. Un país en el que la política no es servicio sino servirse de la manera más cínica y descarada para lucrarse individualmente o para poner todo a favor de los intereses del clan social o del partido político (veáse, por ejemplo, cómo los candidatos de ARENA, el partido en el poder, sea para las elecciones presidenciales, de alcaldes o diputados, se sirven siempre del sistema político para hacer propaganda antes de que el Tribunal Supremo Electoral autorice el inicio de las campañas electorales. Una sociedad basada en la desconfianza, la inseguridad, la improvisación, la corrupción, el machismo, la intolerancia, el fatalismo, etc. En fin, el documento esconde decir directamente que somos una nación sin identidad porque tener identidad implica, según el mismo documento, "condiciones de inclusión, participación y contribución a un proyecto común" de vida y progreso, y en El Salvador, es clarísimo, tales condiciones no existen todavía para las grandes mayorías populares que componen su población, puesto que no hay una democracia económica y social, sino apenas una inmadura democracia política. 
En las Bases para un plan de nación, el tema y problema de la identidad nacional o de la "cultura nacional" en general no se aborda, sino que sólo se menciona y de la manera más superficial. Y lo mismo puede decirse respecto a los documentos que le han seguido: Temas claves para el plan de nación. Consulta especializada $a^{74}$ y Acciones iniciales del plan de nación's; aunque en este último, hay que reconocerlo, existe mayor madurez y criticidad sobre la cultura nacional. Pero de todos ellos, no se desprende directamente una política cultural para el conocimiento, conciencia, valorización, fundamentación y desarrollo de una identidad nacional consciente y crítica en la población salvadoreña; mas pueden servir de mucho para poner en práctica una política cultural nacional en esta línea.

Hay que reconocer, por tanto, la importancia de las Bases para el plan de nación ${ }^{76}$. Pues el documento fue y sigue siendo "una publicación para que el país entre en diálogo" — como afirma el economista Francisco Javier Ibisate-, y su creación, pese a sus eufemismos e ideologizaciones, "es un giro histórico o un cambio de agujas que lo debe tomar en cuenta el nuevo gobiemo" de manera muy seria, ya que es necesario un "Plan de nación que nos dé una visión, a mediano y largo plazo, que genere estabilidad, confianza y continuidad"" en El Salvador.

Las Acciones iniciales del plan de nación, a nuestro parecer, siguen adoleciendo la falta de un diagnóstico crítico nacional, pero son con todo un importante paso en la creación de un Plan de Nación que contenga una política cultural que se ocupe de la identidad nacional, al reconocer que "nuestro país se ha desarrollado hasta ahora con una distorsión grave y profunda". Pues, sus autores son sinceros y claros al señalar que "territorios enteros, vastos segmentos poblacionales e importantes sectores económicos han permanecido ignorados y excluidos de las decisiones y de los beneficios del desarrollo", y que esta es "la razón fundamental por la que no hemos podido construir una nación integrada, estable y próspera"7»

En cuanto a la propuesta que hizo el presidente de la República, creemos que no basta con decir que es necesario "rescatar" la identidad nacional, porque más que rescatarla hay que reinventarla con nuevos valores, como son los valores necesarios para crear un verdadero sistema democrático de vida en El Salvador.

Mas en lo que a rescate se refiere, este se puede aceptar y entender en dos sentidos. Primero en que hay que rescatar la identidad, pero del sueño profundo en que está en el mundo anímico, tanto individual como colectivo, de la mayoría de salvadoreños, y así nos volvamos conscientes de nuestra identidad o de lo que somos como de nuestra realidad o de lo que tenemos como nación en el presente. Segundo, en cuanto a rescatar del olvido "ciertos valores" de antaño, es decir sólo algunos porque no todo lo que fue "valor" en el pasado sigue teniendo validez en el presente - y porque en la historia nacional salvadoreña lo mejor no está en el pasado sino en lo todavia-no-llegado-a-ser (E. Bloch)_, para "descubrir lo aún válido en la herencia cultural" y de ese modo "apropiarnos de lo que aún se 
pueda utilizar" (T. Adomo) en la actualidad. Así, con rescates como estos, sí se podría ayudar a reinventar y construir una nueva idiosincrasia nacional con valores colectivos nuevos y desconocidos por la actual identidad y realidad cultural e histórica salvadoreña. Porque la criticidad, la veracidad, la responsabilidad, la solidaridad, la tolerancia, la honradez, la confianza, etc., son valores que en la historia de la sociedad salvadoreña son y han sido más bien la excepción y no la regla en su casi bicentenaria historia nacional. Y dichos valores deben ser asumidos y practicados por la mayoría de salvadoreños y no sólo por unos cuantos en la vida real de todos los días, si se quiere hacer de la democracia un modo de vida en el país. Pues, la democracia no se da en una nación por decreto, sino gracias al ejercicio cotidiano de sus valores como a la realización de los derechos y deberes que este sistema otorga y exige a sus ciudadanos e instituciones.

\section{1. ¿Qué es lo que más nos identifica como salvadoreños en el presente?}

La identidad no es una cosa, una substancia o un ser que esté por ahí atrapado o perdido en el pasado o en el presente de una persona o sociedad, y que deba simplemente "rescatarse" y luego exponerse públicamente: “¡Aquí está la identidad!" “¡Esta es la identidad de los salvadoreños!”. ¡Nada más absurdo y ridículo! La identidad no se adquiere por el hecho de tener una nacionalidad ni la da un pasaporte o cédula de "identidad personal". No es hereditaria, sino de naturaleza propiamente social y cultural. Pues la identidad es la idiosincrasia o forma de ser que se adquiere en el universo socio-cultural en el que se nace, crece y vive. Es un proceso psico-social sujeto a cambios, tanto en un individuo como en una colectividad. Es una vivencia aprendida y transmitida de generación en generación en el seno de una sociedad o grupo social particular, y que es interiorizada y asumida, consciente o inconscientemente, por cada uno de sus miembros.

En efecto, la identidad es "el enraizamiento de la persona en un determinado mundo de significaciones, así como en una determinada red de relaciones sociales"7y. Por eso "no hay identidad personal que no sea al mismo tiempo y por lo mismo identidad social" humano al que pertenece o del que procede. Todo ser humano es portador de una forma de hablar una lengua, de unas virtudes y defectos, de creencias, principios, preferencias, comportamientos y muchos otros elementos que recibió en un determinado grupo social y cultural, y que experimenta y manifiesta en su país de origen o en el extranjero. Por eso "la cultura es nuestra limitación y nuestra fuerza" - dice el antropólogo y filósofo Antonio Gallo- y "no podemos deshacernos de ella o pretender cambiarla como quien se cambia de camisa"'l. La identidad es parte de nuestro yo personal que, a su vez, es un yo social.

No obstante, como proceso social y cultural que se está construyendo permanentemente, una identidad nacional puede reinventarse respetando las distintas identidades grupales sociales y culturales locales que son su base, fundamentán- 
dose en ellas y trabajando desde ellas para lograr una unidad cultural nacional y un proyecto común de vida.

En El Salvador no es que no exista una identidad nacional, pues hay suficientes elementos históricos, culturales y naturales que nos definen e identifican como ciudadanos de esta república. Lo que sucede es que el grueso de los salvadoreños - por circunstancias históricas y culturales que lo han impedido- no hemos aprendido a identificamos consciente y críticamente con nosotros mismos y menos con los elementos que componen la realidad cultural y natural, social e histórica, geográfica y ecológica, constitucional y cívica, artística y literaria, etc., que nos proporcionan una identidad nacional. Además, por falta de conocimiento, educación y valorización de esa realidad cultural estructural, en El Salvador la identidad no se vive de forma consciente y crítica, sino de la manera más inconsciente y sin criticidad alguna, por lo que los salvadoreños fácilmente caemos en enajenaciones e ideologizaciones que, por paradójico que parezca, nos desidentifican cada vez más tradicionalmente por un lado mientras por otro nos identifican pero sobre todo negativamente, como sucede en el momento presente.

Por consiguiente, en El Salvador hay una identidad nacional pero inconsciente y artificial, y mientras esto sea así ésta será más desidentidad que identidad verdadera. Pues, la mayoría de salvadoreños no tienen identificación ni conciencia con lo que realmente son y tampoco con la realidad que habitan. El salvadoreño vive de falsas imágenes y estereotipos sobre sí mismo — que somos los más trabajadores, los mejores comerciantes, los más acogedores, los más aguantadores, los más machos, etc.- y que alimenta con un patriotismo nacionalista extremista que encubre las más grandes facetas de su verdadera realidad e identidad sociocultural. Esto porque en el país no hay conocimiento ni conciencia de la realidad nacional y por ello de la identidad, pues identidad y realidad marchan juntas, son unidad. Y como no hay unidad entre la una y la otra no hay convivialidad ni visión de conjunto nacional. Cada quien vive y piensa el país desde su grupo y clase social, es decir aisladamente, y no se siente miembro ni parte —en cuanto a deberes y responsabilidades - de un todo socio-cultural nacional. Así, hay más inconsciencia que conciencia identitaria. La sociedad salvadoreña es por eso más caos (desorden) que cosmos (orden).

Y esta situación caótica no es nueva, es decir no es el resultado del llamado "conflicto armado", sino que la guerra civil salvadoreña fue más bien producto y desarrollo de esta inconsciencia identitaria que venimos arrastrando desde, por lo menos, la constitución del país como Estado-nación. La guerra fue una trágica experiencia fratricida que aún nos interpela para volvernos conscientes y críticos de nuestra identidad y realidad presente, y para bien de la memoria colectiva las heridas que causó aún están abiertas. No hemos olvidado la guerra porque todavía duele. Hay luto en muchísimos hogares. Mas, para desgracia de El Salvador, hay sectores que se favorecen de mantener la inconsciencia de lo que somos y 
tenemos. No se ha hecho en verdad un examen crítico sobre las causas que originaron la guerra -muchas de las cuales siguen vigentes: pobreza, marginación, inequidad, injusticia, impunidad, dependencia, etc.- y menos se está pensando en escribir una historia científica sobre la misma. Hay resistencia a un proceso de concientización sobre la identidad y realidad nacional y, por consiguiente, la inconsciencia identitaria persiste en la población. En El Salvador parece no haber pasado nada, y entre la mayoría de la gente, nadie parece querer recordar ni saber el porqué de nuestro ser y realidad nacional. El salvadoreño común y corriente, sea rico o pobre, es un ser feliz cuanto más enajedado está. Su vida consiste en consumir todo lo que el sistema capitalista neoliberal le pone enfrente para devorarlo. La ideosincrasia del salvadoreño consiste más en tener que en ser, en sobrevivir que en vivir.

Los resultados de esta inconciencia identitaria o desidentidad se ven en la vida diaria que llevamos como país. No podemos responder a la pregunta cuál es la identidad de los salvadoreños porque en el presente hace falta estudiarla muchísimo más científica y filosóficamente en el presente, pero, en cambio, a la pregunta qué es lo que más nos identifica en la actualidad como nacionales, cualquiera puede dar respuesta siempre y cuando quiera percibir con sinceridad y criticidad nuestro alrededor para reconocer una serie de elementos identificantes más negativos que positivos que caracterizan nuestra realidad e identidad cultural e histórica contemporánea. Y si tal vez los extranjeros pueden ser más objetivos para esto, leamos como nos describe, por ejemplo, el editorial de un Boletín de la Cámara Alemana-Salvadoreña de Comercio e Industria de este año 1999. En su inicio dice: "El país El Salvador se encuentra en un proceso de cambio: Un nuevo gobierno con caras jóvenes no gastadas que se han propuesto mucho pero quienes tienen que demostrar cuánto será realizable también contra las resistencias de grupos de influencia y lobbies". Y más adelante continua: "Los conflictos en el país son numerosos, las perspectivas no muy alentadoras: El medio ambiente está muriendo y los pasos necesarios se retrasan intencionalmente o por razones financieras, el sistema educativo mejora a pasitos, la delincuencia es fuerte y omnipresente, la industria de la maquila se encuentra en receso con cifras cayentes de empleados, producción y exportaciones, el sector de construcción está casi paralizado, las inversiones extranjeras tras las privatizaciones espectaculares del año pasado relativamente bajas, el pronóstico del crecimiento del PIB se corrigieron claramente hacia menos del 2 por ciento, se habla de deflación" ${ }^{\prime \prime 2}$..

Pero también hay nacionales críticos. El analista Herman W. Bruch describió muy bien, en su columna del martes 5 de octubre, en El Diario de Hoy, la pobre y triste realidad cultural e histórica nacional: "La gente se ha expresado con claridad. Ya no cree en nada. Una gran parte se iría del país. La otra se muere lentamente. ¿Qué nos está pasando? ¡Necesitamos cambios ya!”. Pues considera, y con gran razón, que: "Las encuestas, las haga quien las haga, ya no pueden esconder la realidad. La gente de nuestro país ha perdido la fe y está a punto de 
perder la esperanza. Desconfía de las instituciones porque le han fallado". Y para fundamentar esto, hace un breve repaso sobre lo que ocurre en la nación: "Los partidos políticos han caído en desprestigio y han perdido credibilidad"./ "La Asamblea Legislativa más parece un club social privado, desconectado de la realidad nacional y dedicado al mercantilismo político". / "El presidente anda enredado con su mismo partido y no logra romper las cadenas con los grupos donantes mercantilistas para convertirse en el presidente de todos los salvadoreños". / "El sistema de justicia en general perdió totalmente su credibilidad". / "El Tribunal Supremo Electoral ha sucumbido ante la partidocracia y la politiquería...". / "El país no tiene fiscal...". / "Se descubre el fraude de los diez millones de colones utilizados para comprar votos...". / "El país se derrumba con un simple temporal de lluvia...". / "El tráfico vehicular, especialmente el transporte público, es un verdadero caos y las calles de San Salvador se rompen a pedazos...". / "Se vendieron masivamente los tests de la PAES...". / "Los secuestros, los asaltos, los robos de carros y furgones y el contrabando ya no se soportan...". / "La lista es larga y vergonzosa..." ${ }^{83}$.

El humorista Lito Montalvo nos describe así: "No hay duda de que en este país, tan querido, la gente se las ingenia para todo. Somos campeones, les metemos gol a los gringos y allá nos vamos sin visa, y no hay manera de detenemos... Chaveliamos música, ropa, software. Somos excelentes contrabandistas, aquí hay de todo y si no hay, se lo conseguimos, sólo diga qué necesita y saque el pisto para pagarlo". En El Salvador sostiene: "Importamos cualquier cosa usada: llantas, ropa, autos, repuestos, refrigeradores, etc., etc,. Triangulamos arroz y leche en polvo donada... Donde hay negocio, ahí estará un salvadoreño, siempre listo al business"'s.

Para el columnista Emesto Valiente Durán, luego de un viaje de negocios a Estados Unidos y regresar a El Salvador, compara y encuentra que en el país "todo es viejo; todo es retrasado; todo es pequeño; todo es sucio; todo se mueve a trancazos, en fin todo parece estar mal". Pero lo peor, asegura, es la situación que viven muchos empresarios: "Premios al valor y al coraje nos deberían dar a los empresarios que sobrevivimos con intereses salvajes como los de nuestra banca. Sencillamente no puede salir adelante ninguna empresa salvadoreña con cargas financieras que llegan casi al $20 \%$..." ${ }^{\text {"s }}$.

En El Salvador, "la credibilidad está en entredicho", asegura recientemente un editorial de La Prensa Gráfica: "Uno de los problemas más graves del país es la desconfianza ciudadana, prácticamente en todo, de resultas de una tradición ocultadora, distorcionadora y muy alejada de la debida transparencia"\$s.

Por otro lado, vemos que el gobierno ha gastado millones de colones en varios pasos de dos, tres y hasta cuatro niveles para descongestionar el tráfico vehicular en San Salvador, pero sin planificación ni previsión, por lo que tales obras "requerirán modificaciones en menos de cinco años" o se volverán obsoletas, 
observa el especialista en desarrollo urbano Carlos Umaña Cema, quien en un artículo periodístico compara la construcción del "Puente de Brooklyn" con el "Paso a cuatro niveles del Hermano lejano". El primero símbolo del espíritu de la ciudad de Nueva York y, a la vez, paradigma para políticos, empresarios y constructores "de cómo pensar, hacer y edificar las cosas bien y a largo plazo". Ya que su construcción -iniciada en 1865 y acabada en 1883- "sobrepasó su utilidad y belleza física" y con la misma se "contribuyó a formar culturalmente a todos los ciudadanos de todas las clases de cómo proyectarse en el tiempo", pues "116 años después de su inauguración, el puente sigue funcionando con sus seis carriles y su plataforma peatonal". $Y$ en las condiciones en que tal monumento se realizó, "Nueva York tenía índices de desarrollo humano inferiores a los del San Salvador actual, menor población y capacidad económica y menor desarrollo científico y técnico". Mientras que el "Paso a cuatro niveles del Hermano Lejano" ha sufrido en unos años por lo menos ocho modificaciones al proyecto original, lo que ha sido calificado por "un hermano lejano" como "un juego infantil de Lego entre los ingenieros salvadoreños", de "método del tanteo (tonteo) por una arquitecto" y definido por un filósofo "como el método de las aproximaciones (cambonadas) sucesivas"; es una obra que se ha convertido en fuente de vergüenza para todo el país. Y "el argumento más falaz y odioso" de politiqueros, burócratas y profesionales mediocres, dice Umaña Cema, en defensa de la "construcción en etapas" de este "modemo paso vehicular", es decir que "somos un país pobre y tenemos que concebir nuestras respuestas a los problemas del desarrollo siempre como pobres". Mas, "ahí está la quintaesencia del método poquitero, de la pobreza de espíritu que inunda gran parte de la burocracia" y está en el pensar y obrar de muchos "empresarios y dirigentes políticos" en El Salvador. Pues, "la identidad nacional es una construcción histórica y no un dechado imaginario de virtudes" y "esto implica características buenas y malas de lo que constituye la salvadoreñidad", es decir "de lo que somos como nación". Sí, sostiene Umaña Cerna, la identidad "implica conciencia de nuestras virtudes pero también de nuestros defectos", y los salvadoreños tenemos "virtudes y defectos que no pasan de ser folclóricos o anecdóticos", pero "el problema es que esta mentalidad poquitera y de corto plazo tiene consecuencias desastrosas para el desarrollo nacional..." ${ }^{87}$.

El panorama salvadoreño es desolador - asegura el columnista e historiador Roberto Turcios-, pues por un lado se padece la secuela de la pobreza y, por otro, no se cuenta con una estrategia dirigida a modificar el atraso cultural ${ }^{8 \mathrm{t}}$.

"Dondequiera que se vea, por todos lados, se encontrará desencanto", expresa el poeta y escritor Miguel Huezo Mixco. Sostiene que "El Salvador parece estar sumergido en un baño de realidad demasiado intenso. $Y$ aunque existan cosas bien hechas y personas que merezcan confianza, la tónica general del estado de ánimo de los salvadoreños es de un creciente pesimismo". Confirma que "el desencanto se percibe en los periódicos, en las calles, en las reuniones familiares". Mas, 
a su parecer, “donde ya ha cristalizado de manera indeleble es en la literatura" y "el mejor ejemplo es El asco, la novela de Horacio Castellanos Moya, que ha llegado a su tercera reimpresión desde que fue publicada en 1997"84.

Tal parece que nuestra sociedad está corrompida, desmoralizada, "baja de moral". "Una sociedad o una persona están corrompidas cuando han ido perdiendo la sustancia que les es propia"*), sostiene la filósofa española Adela Cortina. Es decir, se corrompen cuando se desnaturalizan y deshumanizan.

El mismo vicepresidente de la República, Carlos Quintanilla Schmidt, reconoce que somos un país que se ha corrompido: "La corrupción está presente en todos los niveles de la vida. Está presente en la sociedad civil, en los mismos medios de comunicación, en las empresas particulares, privadas y estatales por

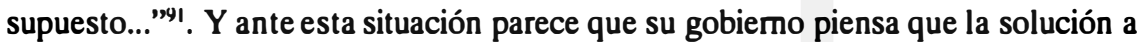
la corrupción es la privatización ${ }^{42}$. Desgraciadamente, el transporte público, que es una empresa privada de "gran peso" en todo el país -y de la cual son propietarios diputados, políticos, militares y otros más-, muestra todos los días que la solución no está necesariamente en la privatización de empresas y servicios, pues siendo este un sector privado es uno de los más corruptos de la sociedad, y esto lo demuestra cotidianamente la conducta irracional e irresponsable de buseros y microbuseros quienes constantemente violan la ley de tránsito, atropellan usuarios y peatones, cometen graves accidentes hiriendo y asesinando personas por doquier y, además, no dejan de contaminar el aire con sus unidades enfermando y matando a miles de niños cada año. Entonces, ¿es realmente la privatización el problema a tanta corrupción social y cultural?

La solución a la corrupción parece estar más bien en un cambio de mentalidad colectiva, en una ética forjadora de un nuevo carácter, en la recuperación y sobre todo creación e importación de valores, en la reinvención y construcción de una nueva identidad; en definitiva, en una revolución cultural en toda nuestra sociedad. Una revolución que no tiene nada que ver con ese gastado discurso conservador y dogmático gubernamental sobre el "rescate de los valores", como si los salvadoreños tuviéramos un pasado glorioso y lleno de valores del cual sentirnos orgullosos. Ya lo dijimos, lo mejor de la sociedad salvadoreña no está en su pasado sino en lo todavía-no-llegado-a-ser. La revolución cultural que necesitamos no debe caer en ningún momento en esa "moral provinciana"y.3 que pregonan tantos santurrones en el país, como tampoco debe ceder a la tendencia socio-cultural intemacional que se propaga a diestra y siniestras desde una "religión política neoconservadora"44.

Pues estas son salidas fáciles, como indica Roberto Turcios. Y ejemplos de moralismo y conservadurismo son las recientes batallas contra las "fuerzas del mal" que libran nuestros diputados, y que este columnista ha analizado muy bien: "Las corrientes conservadoras se anotaron un nuevo triunfo. Antes, la Asamblea Legislativa dictaminó sobre el origen de la persona (condenó todo tipo de aborto 
pensando más con las entrañas que con la razón, gritando al unisono jsi a la vida!), ahora sobre los juegos lícitos (decidió quitarle a las alcaldias la facultad de autorizar el funcionamiento de casinos y eliminar asi estos "centros del vicio y del mal") y muy pronto quizás se pronuncie respecto a la educación religiosa. No habrá que extrañarse si algunos diputados también deciden elaborar el perfecto manual de las buenas costumbres. Todo se vale cuando de improvisar se trata". En efecto, "durante este siglo, El Salvador no ha tenido una respetable tradición liberal. En el ejercicio del poder ha valido más la doctrina autoritaria, o francamente totalitaria, que los postulados liberales, y en la vida social ha sido mayor la cultura patriarcal. Tal vez esa herencia sea la que provoca tanto apego a las prohibiciones cuando se abordan los problemas nacionales". Pues "uno de los puntos más importantes en el liberalismo es el derecho de la persona para regirse en la vida como mejor le parezca y con aneglo a las leyes. En El Salvador actual hay una corriente de opinión, muy extendida en los medios de comunicación y en la política, que quisiera poner al Estado a uniformar las costumbres y creencias de la gente. Se trata de una mentalidad conservadora, inconsistente y muy dada a improvisar. Y mientras en unos temas reinan enfoques intervencionistas, en otros, como la posesión de armas y seguro obligatorio de vehículos, impera la condescendencia"

Y la realidad salvadoreña es tal, que no tarda en dar de sí pero siempre más en mal que en bien. Unos días después de las críticas de Turcios, escritas en su columna, un diputado y su partido osaron presentar una iniciativa que sugería "por lo menos unos cinco minutos de lectura de la Biblia" en las escuelas y colegios del país para "fomentar en la niñez salvadoreña virtudes y valores que orienten su desarrollo integral". Es decir, no estaban lejos de proponer un Estado confesional. Pero la presidencia de la Federación de Asociaciones de Abogados, Beatrice de Carrillo - una señora de origen italiano pero salvadoreña por opción y corazón-, fue firme al asegurar en nombre de su institución que dicha iniciativa violaba la constitución, y además señaló: "Los diputados deberían tener una mínima base constitucional para defenderse en la Asamblea ${ }^{\%}$.

Sí, lo que más nos identifica "hoy por hoy" a los salvadoreños es ser, en gran medida, una sociedad sin responsabilidad, sin productividad, sin solidaridad, sin tolerancia, sin humanismo, sin planeación y sin respeto a las leyes como podríamos serlo. Somos una sociedad corrompida. Y si se dice que para muestra "un botón", en el país sobran. Criminales, ladrones, buseros, microbuseros, mareros, conductores patanes salidos de todos los niveles sociales, usureros, politiqueros, pistoleros, depredadores del medio ambiente y estudiantes, profesionales mediocres y mercantilistas, todos ellos en el número y grado como existen hoy en el país, son, con sus actividades antisociales diarias, ejemplos del mayor grado de involución y degeneración, es decir de corrupción, jamás visto ni superado en la historia de esta nación. 
Entonces, en las actuales circunstancias nacionales ser salvadoreño quizás nos cause más vergüenza que orgullo. Mas cuando hay vergüenza hay todavía dignidad, y si hay dignidad hay todavía esperanza. Esperanza para transformar lo que nos avergüenza e indigna, y por ello hay también utopía. Utopía en el sentido de crear una nueva sociedad salvadoreña. La utopía de modificar la identidad y realidad socio-cultural existente en El Salvador.

\section{Necesitamos conciencia, criticidad y "esperanza inteligida"}

En fin, el que seamos caos y no cosmos social y cultural es evidente también en la vida fatalista y resignada que llevamos cotidianamente los salvadoreños. Pareciera que, aparte de unos pocos, nadie hace nada ni quiere saber nada por cambiar las muchísimas cosas que están mal. La contralectura que hemos hecho de las Bases para el plan de nación y las descripciones y reflexiones críticas que hemos reproducido, resumen muy bien nuestra verdadera identidad y realidad contemporánea. Dejan al descubierto nuestra triste y pobre situación cultural e histórica, es decir lo que El Salvador es, lo que los salvadoreños somos y aceptamos fatalista y resignadamente y que no queremos reconocer, pero que es necesario hacerlo para dejar de ser caos y luchar por construir un cosmos sociocultural en El Salvador.

Lo que en este país necesitamos para cambiar es hacer un diagnóstico sociocultural en casi todo lo que realmente somos como nación, para luego pasar a un pronóstico de lo que queremos cambiar y porqué, si en verdad deseamos llegar a ser y tener un país diferente al que somos y tenemos hoy, y así lograr una revolución cultural. Pero para esto se necesita comenzar por un ejercicio crítico.

Sí, necesitamos de un ejercicio crítico "sin adjetivos", como expresa Roberto Turcios, para analizar la realidad nacional: "Arriba los ánimos, dice una campaña de la Asociación de Medios Publicitarios que invita a respetar la democracia y a tener el espíritu renovado. Sin lugar a dudas, la renovación es una necesidad, en especial en la política y en primer lugar de los titulares del poder público. Y un buen ejercicio para levantar los ánimos y renovar el espíritu es el de la crítica"'97. Una crítica, afirma Turcios, que no debe limitarse a calificativos como "propositiva" o "constructiva". Pues "la crítica es ante todo un ejercicio intelectual encaminado a examinar problemas y desmontar falsedades. La prueba de su validez la obtiene en el debate, no por algún calificativo previo..." "9y

Por tanto, hay que "rescatar" la identidad nacional pero en el sentido de despertarla y volverla consciente y crítica en la mayoría de salvadoreños. Es necesario hacerlo para reconocer lo que somos y mirar hacia lo que queremos dejar de ser, y así trabajar todos los salvadoreños como nación unida en revertir y transformar lo que nos desnaturaliza, deshumaniza y enajena, lo que imposibilita nuestro desarrollo cultural e histórico, y así de ese modo reinventar y construir una identidad-realidad salvadoreña diferente a la que tenemos en el presente, tras- 
cendiendo lo muchísimo de negativo que hay y conservando lo que de positivo aún nos queda. Y entre lo positivo que nos queda está nuestra vergüenza, y por poco que parezca, es más bien algo muy grande y valioso. Porque mientras haya todavía vergüenza en El Salvador, habrá dignidad y por tanto esperanza y utopía.

Los salvadoreños podemos hacer de la democracia y sus valores un proyecto de identidad nacional que se vuelva modo de vida; es decir, podemos interiorizar e institucionalizar sus valores y volverlos una característica esencial de nuestra idiosincrasia, ya no sólo exigiendo derechos sino también cumpliendo con nuestros deberes ciudadanos. Pero para esto hay que realizar un arduo trabajo de concientización en la población y especialmente en los sectores detentores del poder económico, político y social -quienes son los que más se resisten a los cambios y los que más se aprovechan de que seamos caos y no cosmos-, para que los salvadoreños logremos tener una conciencia de nuestra verdadera realidad e identidad. Porque no hay identidad consciente sin una conciencia de la realidad en que se vive. Y sin conciencia de lo que se es y se tiene no hay posibilidades de cambios para mejorar y desarrollarse cultural e históricamente.

Con las correcciones pertinentes, le tomamos la palabra al señor presidente, aunque no sabemos si tiene o no un proyecto consciente y crítico de "rescate de la identidad". No obstante, al poner en marcha una "estrategia de rescate" consideramos que el "nuevo gobierno" de ARENA no debe continuar con los viejos errores y vicios del pasado inmediato y antiguo, como es seguir manteniendo una identidad a nivel de Estado-nación. Es decir, esperamos que no persista en la pretensión de querer construir una identidad nacional "nacionalista" y "populista" desde sus políticas estatales ideologizadas, ya que esto significa repetir la equivocación de siempre: sostener una identidad nacional homogénea, monocultural, uniforme y unidimensional como se ha venido haciendo desde la independencia centroamericana. Pues, una identidad así no surge del mundo real que es la población y situación socio-cultural salvadoreña presente, sino de ideas, estereotipos, prejuicios y caprichos creados desde las élites y sus aparatos y poderes del Estado, por lo que resulta una identidad oficial pero nacionalmente falsa. Esto es una burla y un engaño. Es una trillada manera de deformar y encubrir la verdadera realidad e identidad salvadoreña en favor de beneficios económicos, políti$\cos$ y sociales minoritarios. Y esto no es otra cosa que manipulación y apropiación de la identidad de una nación.

Un ejemplo claro de la manipulación y apropiación de la identidad salvadoreña son las celebraciones cívicas anuales del día de la independencia, en las que se repite eternamente sin conciencia y sin criticidad lo mismo: los símbolos patrios dejan de ser símbolos y terminan reemplazando lo que simbolizan. Se le rinde un culto ciego a la bandera y su oración, al himno y al escudo y no se cae en la cuenta que tras de estos símbolos está la verdadera y olvidada, la real e irrespetada, la concreta y cotidianamente deshumanizada y desnaturalizada pa- 
tria salvadoreña. Una población compuesta por millones de mujeres y hombres en su mayoría inmensamente pobres, condenados a "una situación de miseria opresiva" y a una "condición de dependencia marginante que les impone una existencia inhumana y les arrebata su capacidad para definir su vida". Una sociedad con serios y profundos atrasos socio-culturales, y en la que sus gobiernos de turno poco o nada han hecho y hacen por un desarrollo cultural nacional. Un territorio que no dejamos de contaminar, depredar, empobrecer y exterminar, pero que no vemos ni conocemos y al que no se nos enseña a ver ni conocer como verdadera y tristemente es.

Nuestro lema "Dios, unión, libertad" ha perdido todo valor y significado en nuestra sociedad por esa manipulación y apropiación gubernamental-partidista de la identidad-realidad del país. Pues en El Salvador, una sociedad que se dice cristiana, no se acata social y culturalmente los principios y valores cristianos, sino más bien antivalores cristianos, pues a diario vivimos el odio en lugar del amor, la muerte en lugar de la vida, la mentira en lugar de la verdad, el robo público en lugar del servicio público, etc. En una sociedad así, ¿puede tenerse a Dios como lema nacional? En otro sentido, no hay unión en el país, sino división e insolidaridad por falta de equidad y justicia. Tampoco hay libertad porque la mayor parte de la población, por la "situación de miseria opresiva" y por la "condición de dependencia marginante" en que vive, es una población a la que se "le imponen una existencia inhumana y se le arrebata su capacidad para definir libremente su vida".

Las fiestas cívicas deberían ser días de reflexión y debates críticos sobre la identidad y la realidad nacional, para analizar nuestras debilidades y errores que son muchísimos y nuestras fortalezas y virtudes que, hoy por hoy, son muy pocas y contadas. Son fechas que deberían dedicarse a actos de solidaridad entre todos los salvadoreños y particularmente en solidaridad con los "más pobres de los pobres" y con el no menos pobre medio ambiente salvadoreño; y no esperar a que vengan huracanes y terremotos para sacar la "caridad" a la luz y la preocupación por el ecosistema nacional.

Seguir manteniendo las celebraciones cívicas sin conciencia ni criticidad de la identidad y realidad nacional del país, es seguir fomentando una "identidad nacional nacionalista" que no lleva a ninguna parte, ya que la identidad oficial que se propicia no posee fundamentos en la realidad cultural e histórica del país y no proporciona sentido de unidad nacional en la población.

Asimismo, la explotación del fútbol como deporte nacional es otro recurso patriotero nacionalista, pero que ya no funciona con una federación futbolera corrupta y una "selección nacional" que está por el suelo y con la que ya nadie se identifica a parte de los fanáticos y los explotadores del pueblo.

Entonces, El Salvador no es un país que esté mal, sino muy pero muy mal social, ecológica y culturalmente hablando, por lo que se necesita de un patrio- 
tismo real y no de uno patriotero con el fin de que los salvadoreños reconozcamos nuestra identidad-realidad enferma y no sigamos conformándonos con ella. Pues está tan mal, que tal situación conduce a una terrible y angustiante paradoja al preguntase si se puede amar este país sin a la vez odiarlo. Sí, odio a lo mal que está y a las raíces de tanto mal. Unas raíces arraigadas, por desgracia, más en el mismo ser de los salvadoreños que en cualquier otra causa o circunstancia.

Pues, ¿qué puede decirse de una nación calificada como una de las regiones con más violencia en el mundo y en la que sus diputados, jlos padres de la patria!, recomiendan y facilitan a los ciudadanos armarse, como medida para contrarrestar la violencia? Únicamente puede decirse que ésta es una sociedad enferma.

Cierto, el país no está muerto, pero se nos muere porque nosotros lo estamos matando y dejando morir. Mas pareciera que no hay conciencia y menos criticidad ante nuestra preocupante realidad e identidad nacional. No obstante es imprescindible despertarlas para que tengamos esperanza. Esperanza para revivir la nación rescatándola de tanta irracionalidad, irresponsabilidad y pobreza material y espiritual.

Sí, además de conciencia y criticidad los salvadoreños necesitamos esperanza. Mas una "esperanza intelegida"wy y no una centrada en esperar pero sin saber qué esperar. Es decir, estamos urgidos de una esperanza que resulte de la conciencia y criticidad necesaria que hemos expuesto, para estar a la espera de una sociedad nueva en El Salvador. Una espera resultado de un hacerse cargo de la realidad salvadoreña con conciencia y criticidad para transformarla.

Pues "lo grave de una sociedad baja de moral no es tanto que en ella se cometan corrupciones y transgresiones concretas, como que el tejido social esté tan falto de sol, de vitaminas y de entrenamiento, que sea incapaz de responder dignamente a la realidad"(10).

"La realidad no tiene un tamaño determinado", decía el filósofo de la esperanza Ernst Bloch. "El mundo no se ha acabado todavía. Es posible enfrentarse al mundo de una manera que vaya más allá de un simple asimiento... Aceptar las cosas como son no es una fórmula empírica válida. No es positiva sino, por el contrario, es una fórmula que conduce a la vulgaridad, a la cobardía y, por último, a la pobreza"101.

Amar al país significa ante todo, y aunque duela, reconocer la realidad que más lo identifica, por vergonzosa e indignante que sea, y no conformarse con ella. Amar la patria es lučchar contra lo que más la desnaturaliza y deshumaniza, sobre todo cuando esto es ocasionado en gran medida por nosotros mismos, sus ciudadanos.

Sí, si decimos amar El Salvador, es preciso que todos asumamos con conciencia y criticidad su patológica y caótica realidad nacional y seamos responsables ante la misma — antes de que sea demasiado tarde -, para transformarnos y 
así transformar nuestra realidad e identidad salvadoreña. Sólo de este modo habrá verdadera esperanza.

\section{Conclusiones}

(1) Las identidades nacionales, por tanto, deberían entenderse para su construcción o fortalecimiento como unidades que resultan de la suma de un conjunto de elementos culturales comunes y compartidos por diversos grupos que componen la población de un Estado-nación, donde sus ciudadanos permanecen unidos por una conciencia crítica nacional, un espacio geográfico-ecológico, una serie de elementos y manifestaciones culturales comunes, una memoria histórica y un presente con proyectos futuros de vida.

Por ello, sabiamente, Octavio Paz aconsejaba "luchar en contra de lo que uniforma sin unir y luchar a favor de lo que une sin uniformar". Y en palabras del filósofo Alejandro Serrano Caldera, de lo que se trata es de buscar "la unidad en la diversidad".

(2) Preocuparse por el problema de la identidad nacional en El Salvador, para descubrir lo que hay de cierto y de falso, de concreto y de fantasía en esto, de manera científica y filosófica, es una de las tareas prioritarias a realizar en esta transición hacia la democracia. Pues los salvadoreños no podremos crear un verdadero Plan de nación en el que se diga, con fundamentos serios y posibilidades reales de realización, qué queremos ser o quiénes queremos llegar a ser como nación en el siglo y milenio futuro, cuando en el presente actual ni siquiera estamos seguros de lo que somos como sociedad y cultura, y ni sabemos cómo, histórica y culturalmente, hemos llegado a ser lo que hoy somos.

(3) Hay que superar el desinterés, el desdén, la apatía y la ignorancia tanto del gobierno como del sector privado hacia los estudios históricos, arqueológicos, antropológicos, literarios, sociológicos, filosóficos, etc., e interesarse por apoyar e invertir en los esfuerzos personales y colectivos de muchos investigadores preocupados por estudiar la realidad histórica y cultural nacional. Estudios sin los cuales los salvadoreños no podremos apropiamos de nuestras posibilidades reales de transformación, progreso y autorrealización.

(4) El estudio de la identidad nacional, sabemos, no es nada fácil. Necesita de todos los saberes filosóficos y científicos. Su estudio nunca se acaba porque la identidad es un fenómeno socio-cultural siempre en proceso. Y por eso mismo la identidad de un pueblo o nación siempre está en construcción permanente desde su presente y por ello de muchos modos puede reinventarse. El presente es la clave pero con memoria histórica. Pues el presente ha sido posibilitado y determinado por un pasado colectivo y, por tal razón, la población de toda nación siempre está urgida de memoria histórica. Memoria de un pasado que necesita ser recuperado y asimilado por la conciencia de un pueblo, porque, como se ha 
dicho, "sin historia no se es y con una historia falsa, ajena, se es otro pero no uno mismo".

(5) Necesitamos construir una identidad nacional consciente, pero también crítica y por ello abierta a los nuevos tiempos. Tiempos en los que las identidades nacionales de cualquier país no pueden quedarse atrapadas en "una noción tradicional de identidad", es decir, concebida como "una defensa de lo nacionalpopular", como "un culto a los orígenes", como "una reivindicación de la pureza de lo vernacular (lo originario, lo autóctono) frente a lo que se considera el efecto contaminante y enajenante de la modernización extranjera", en fin, como "un universo autónomo, coherente y negándose a influencias exteriores, aunque históricamente haya cumplido su función", pero que en una época postmoderna y en una sociedad globalizada como la que vivimos en el mundo actual "es difícilmente sostenible", como asegura con gran razón el especialista en estos temas Fernando Aínsa ${ }^{102}$.

La identidad, como realidad cultural e histórica, es siempre proceso, construcción, devenir. "Es una ecuación dinámica donde se combinan inextricablemente elementos más o menos estables con elementos cambiantes y relativamente imprevisibles ${ }^{113}$.

(6) Un estudio moderno sobre la identidad nacional de un país y, especialmente, para promover su conocimiento, valoración y conciencia, no puede quedarse en la promoción de un discurso nacionalista patriotero como "Primero El Salvador, segundo El Salvador y tercero El Salvador". Este debe, más bien, basarse en las realidades históricas y culturales que se viven e imponen mundialmente, como son la integración regional y la globalización internacional, realidades que "no deben confundirse", necesariamente, con "homogeneización" o "uniformización". Pues no es posible ni deseable cerrarse al intercambio comercial, tecnológico, científico y cultural que prevalece en el mundo actual. Se debe promover, más bien, un nacionalismo sano, maduro, crítico y abierto al mundo.

Porque la cuestión fundamental contemporánea, como ha explicado el maestro y filósofo cubano Raúl Fornet-Betancourt, no es preguntarse "cómo integrar lo propio en el movimiento de lo universal, sino cómo injertar la diversidad del mundo en lo propio":1/4, ya que "la finitud humana, tanto a nivel individual como cultural, impone renunciar a la tendencia, tan propia a toda cultura, de absolutizar o de sacralizar lo propio; fomentando por el contrario el hábito de intercambiar y de contrastar" "us.

En este sentido, por tanto, y parafraseando al filósofo, podemos decir que para la reinvención de una identidad nacional debemos "partir de la propia tradición cultural", mas esto hay que hacerlo "sabiéndola y viviéndola no como instalación absoluta sino como tránsito y puente para la inter-comunicación". Nuestra identidad cultural e histórica "sería de este modo algo así como el puente que 
no podemos saltar, pero que debemos transitar si queremos llegar a la otra orilla"106, o sea lograr insertamos en la sociedad globalizada y universal que se impone en el mundo, pero conservando nuestro deber y derecho a ser diferentes como latinoamericanos, centroamericanos y salvadoreños.

(7) Para transformar el caos social actual en un cosmos social en El Salvador es urgente y necesario una toma de conciencia crítica sobre la realidad y la identidad nacional, pero esto sólo será posible por medio de un proceso de concientización crítico en la población salvadoreña.

En efecto, necesitamos de un proceso de concientización crítico que dé esperanza y, como decía Martín-Baró, que apunte "al problema de la identidad tanto personal como social, grupal y nacional". Una concientización que lleve "a las personas a recuperar la memoria histórica, a asumir lo más auténtico de su pasado, a depurar lo más genuino de su presente y a proyectar todo ello en un proyecto personal y nacional" de vida.

\section{Anexo}

\section{Esbozo para una bibliografía identitaria salvadoreña}

(1911/1985) Martín, Percy Falcke. El Salvador del siglo XX (1ª edición publicada en Londres, bajo el título Salvador of the twentieth century, 1911), San Salvador, UCA Editores, 1985.

(1840-1935/1978) Baily, J.; Rippy, F.; Martin, P.F.; De Périgny, M.; Munro, D.G.; Wilson, E. A.; y Grieb, K. J. El Salvador de 1840 a 1935. Estudiado y analizado por extranjeros, selección y notas de Rafael Menjívar y Rafael Guidos Véjar, San Salvador, UCA Editores, 1978.

(1942/1996) Barón Castro, Rodolfo. La población de El Salvador (1'a edición, publicada en Madrid, por el Consejo Superior de Investigaciones Científicas, Instituto Gonzalo Fernández de Oviedo, en 1942), San Salvador, UCA Editores, 1978; Reseña histórica de la villa de San Salvador (1ªdición publicada en Madrid, por Ediciones Cultura Hispánica, en 1950), San Salvador, División de Publicaciones e Impresos y CONCULTURA, 1996; José Matias Delgado y el movimiento insurgente de 1811, San Salvador, Dirección General de Publicaciones, 1962.

(1961-1978) Geoffroy Rivas, Pedro. Toponimia nahuat de Cuscatlán (1ª edición, publicada en San Salvador, Editorial Universitaria, 1961), San Salvador, Dirección de Publicaciones, 1982; La lengua salvadoreña, San Salvador, Ministerio de Cultura y Comunicaciones, Dirección de Publicaciones e Impresos, 1978.

(1961) Gallardo, Ricardo. Las Constituciones de El Salvador (dos tomos), Madrid, Ediciones de Cultura Hispánica, 1961. 
(1969-1982) Roque, Dalton, Taberna y otros lugares, La Habana, Casa de las Américas, Cuba, 1969; Las historias prohibidas del pulgarcito (textos y poemas), México, Siglo XXI Editores, 1973; El Salvador (monografía), San Salvador, Editorial Universitaria de la Universidad de El Salvador, 1979; Pobrecito Poeta que era yo (novela póstuma), San José, EDUCA, 1982.

(1969-1991) Ellacuría, Ignacio. Veinte años de historia en El Salvador (19691989). Escritos políticos (tres tomos), San Salvador, UCA Editores, 1991.

(1970) Yanes Díaz, Gonzalo. Las iglesias coloniales en El Salvador, San Salvador, Editorial Universitaria, 1970.

(1971) Browning, David. El Salvador, la tierra y el hombre (1 $1^{\mathrm{B}}$ edición, publicada bajo el título El Salvador Landscape and society, Londres, Oxford University Press, 1971), San Salvador, Dirección de Publicaciones del Ministerio de Educación, 1975.

(1971) Anderson, Thomas. El Salvador 1932 (1 edición, publicada bajo el título Matanza: El Salvador'comunist Revolt of 1932, Lincoln, University Press, 1971, San José, EDUCA, 1982.

(1973) White, Alastair. El Salvador (1' edición, publicada bajo el título El Salvador, New York, Praeger Publishers, 1973), San Salvador, UCA Editores, 1983.

(1974) López Vallecillos, Italo. El periodismo en El Salvador, Editorial Universitaria, Universidad de El Salvador, 1974.

(1974) Armas Molina, Miguel. La cultura pipil de Centroamérica, San Salvador, Ministerio de Educación, Dirección de Publicaciones, 1974.

(1977) Montes, Santiago. Etnohistoria de El Salvador. Cofradias, hermandades y guachivales (en dos tomos), San Salvador, Dirección de publicaciones, 1977.

(1979-1990) Montes, Segundo. El compadrazgo. Una estructura de poder en El Salvador, San Salvador, UCA Editores, 1979; El agro salvadoreño (19731980), San Salvador, UCA Editores, 1986; El Salvador 1989. Las remesas que envían los salvadoreños de Estados Unidos. Consecuencias sociales y económicas, San Salvador, UCA Editores, 1990.

(1979-1995) Escobar Galindo, David. El árbol de todos. Lecturas Hispanoamericanas, San Salvador, Dirección de Publicaciones del Ministerio de Educación; Índice antológico de la poesía salvadoreña, San Salvador, UCA Editores, 1982; “Un país que se resiste a recordar", Revista Tendencias, 43, 1995, p. 14.

(1980) Argueta, Manlio. Un día en la vida (novela), San Salvador, UCA Editores, 1980. 
(1982-1995) Guido Béjar, Rafael. Ascenso del militarismo en El Salvador, San José, EDUCA, 1982. Y también Rafael Guido Béjar y Stefan Roggenbuck (eds.): Sociedad participativa en El Salvador, Fundación Konrad Adenauer/ UCA, 1995; El Salvador a fin de siglo, San Salvador, Fundación Konrad Adenauer/UCA, 1995.

(1984) Martínez Amáiz, José Ignacio. Ecología, San Salvador, UCA Editores, 1984. (Obra en la que se analizan desde la ciencia ecológica los problemas del medio ambiente salvadoreño.)

(1985-1986) Instituto Geográfico Nacional "Ingeniero Pablo Amoldo Guzmán”. Diccionario Geográfico de El Salvador, Tomo I, A-K (1985), Tomo II, L-Z (1985), (La Toponimia Nahuat de las cabeceras municipales corresponde a las diferentes interpretaciones que establecen en sus obras: Tomás Fidias Jiménez, Pedro Geoffroy Rivas, Jorge Larde y Larín y Próspero Arauz), San Salvador, 1985-1986.

(1985-1988) Lungo Uclés, Mario. El Salvador 1981-1984. La dimensión política de la guerra, San Salvador, UCA Editores, 1985; La lucha de masas en El Salvador, San Salvador, UCA Editores, 1987; El Salvador de los 80: contrainsurgencia y revolución, San Salvador, Editorial Universitaria, 1991; La estructuración de las capitales centroamericanas de Rodrigo Femández y Mario Lungo Uclés, San José, EDUCA, 1988.

(1987-1991) Lara Martínez, Rafael. Del 32 como mito o la visión del vencido, Estudios Centroamericanos (ECA), 463-464, 1987, pp. 323-335; Historia Sagrada e Historia Profana. El sentido de la historia salvadoreña en la obra de Francisco Gavidia, San Salvador, Dirección de Publicaciones, 1991; Salarrué o el mito de la creación de la sociedad mestiza salvadoreña, San Salvador, Dirección de Publicaciones del Ministerio de Educación, 1991 (107 páginas).

(1990) Mac Chapin, N. La población indigena de El Salvador, San Salvador, Colección antropología e historia, 20, Dirección del Patrimonio Cultural, 1990.

(1990) Navarro, Ricardo; Pons, Gabriel y E. Amaya, German. El pensamiento ecologista, San Salvador, Centro Salvadoreño de Tecnología Apropiada (CESTA), 1990.

(1992) Rodríguez Díaz, Rafael. Temas salvadoreños, San Salvador, UCA Editores, 1992; Indoamérica en flor, México, Departamento de Comunicación Cultural/Instituto Chiapaneco de Cultura, Serie Centromérica, 1994; "Tres tareas para el escritor salvadoreño contemporáneo", Realidad, 57, 1997, pp. 293 303; “Memorias de un fauno en su jardín”, Realidad, 67, 1999, pp. 95-128. 
(1992-1998) Wauthion, Emesto. "Cronología de una guerra civil anunciada", Diálogo, 2, 1992, pp. 37-61; “¿Por qué prehistoria si hay historia precolombina?", Suplemento Tres Mil, Diario Latino, 29 de agosto de 1992; "Nuestra América y la continuidad del Pueblo Profundo" (I), Suplemento Tres Mil, Diario Latino, 12 de septiembre de 1992; "Nuestra América y la continuidad del Pueblo Profundo. Significado y valor actual de las culturas y civilizaciones prehispánicas mesoamericanas" (II), Suplemento Tres Mil, Diario Latino, 26 de septiembre de1992.

(1993) Comisión de la Verdad. De la locura a la esperanza (La guerra de 12 años en El Salvador). Informe (1992-1993), San Salvador, Editorial Universitaria, 1993.

(1993) Danner, Mark. The Massacre El Mozote, New York, Vintage Books, 1993. (Para un resumen de esta investigación periodística, ver Danner, Mark; Amaya, Rufina y Santiago. Luciérnagas en El Mozote, San Salvador, Ediciones Museo de la Palabra, 1996.)

(1993-1997) Castellanos Moya, Horacio. Recuento de incertidumbres, San Salvador, Ediciones Tendencias, 1993; "Consideraciones sobre educación, cultura e identidad”, Revista Tendencias, 21, 1993, pp. 27-28; El asco (novela), San Salvador, Editorial Arcoiris, 1997.

(1993-1994) Huezo, Roberto. "Fundamentos de la cultura nacional", Revista Tendencias, 22, 1993, pp. 23-26, 1993; "Modemidad. Modernización. Modernismo. Un acercamiento a la estética: 1880-1930". En Stefan Roggenbuck (editor), Cultura y desarrollo en El Salvador, San Salvador, Fundación Konrad Adenauer, 1994.

(1993) de Gutiérrez, Gloria Aracely. Tradición oral de El Salvador, San Salvador, CONCULTURA/Dirección General de Publicaciones e Impresos, 1993.

(1993-1997) Vázquez, Mario R. Bibliografia historiográfica de El Salvador, San Salvador, 1993 (inédito); "Entre la monarquía y la República jsupremo instante! Una polémica de la independencia", Cultura, 80, 1997.

(1993) Lara Martínez, Carlos. "Consideraciones sobre la problemática indígena en El Salvador", Boletín del Departamento de Antropologia, Concultura, 1993; Salvadoreños en Calgary: el proceso de configuración de un nuevo grupo étnico, San Salvador, Dirección General de Patrimonio Cultural, 1994; "La cultura salvadoreña en tiempos de guerra y de paz: elementos metodológicos para su estudio", Cultura, 76, 1994, pp. 15-29; "Transformación sociocultural". En Oscar Martínez Peñate (coordinador), El Salvador. Sociología General, San Salvador, Editorial Nuevo Enfoque, 1999, pp. 41-53.

(1993) Turcios, Roberto. Autoritarismo y modernización. El Salvador 1950-1960, San Salvador, Ediciones Tendencias, 1993; Los primeros patriotas. San Sal- 
vador 1811, San Salvador, Ediciones Tendencias, 1995; "Identidad de migrantes", La Prensa Gráifica, 31 de octubre de 1995.

(1994) Roggenbuck, Stefan (editor), Cultura y desarrollo, San Salvador, Fundación Konrad Adenauer, 1994.

(1994) Cobos, Rafael. Sintesis de la arqueología de El Salvador, San Salvador, Colección antropología e historia, 21, Consejo Nacional para el Arte y la Cultura (Concultura), Dirección General del Patrimonio, 1994.

(1994) Escalante Arce, Pedro. Apuntes sobre mestizaje y transculturación en las provincias hispano-salvadoreñas. En Cultura y desarrollo en El Salvador, San Salvador, Fundación Konrad Adenauer, 1994, pp. 11-41.

(1994) Andrés Escobar, Francisco. "Los turbios hilos de la sangre. Una aproximación al problema de la identidad cultural". En Stefan Roggenbuck, Cultura y desarrollo en El Salvador, op. cit., 1994, pp. 103-154; "Pueblos en cruz: la sociedad civil en la cultura". En Sociedad participativa en El Salvador, editado por Rafael Guido Béjar y Stafan Roggenbuck, San Salvador, Fundación Konrad Adenauer, 1995, pp. 63-100.

(1994) Escamilla, Manuel Luis. Hispanoamérica en la ruta de su identidad, San Salvador, Dirección General de Publicaciones e Impresos, Concultura, 1994.

(1994) Huezo, Roberto; Lindo Fuentes, Héctor y Walter, Knut. Historia de El Salvador (dos Tomos), San Salvador, Ministerio de Educación, 1994.

(1995-1999) Huezo Mixco, Miguel. La casa en llamas: decadencia y renovación cultural en El Salvador. En El Salvador a fin de siglo, editado por Rafael Guido Béjar y Stefan Roggenbuck, San Salvador, Fundación Konrad Adenauer, 1995, pp. 203-263; "La identidad", La Prensa Gráifica, 29 de julio de 1999.

(1994-1995) Lindo Fuentes, Héctor. "La introducción del café en El Salvador". En Tierra, café y sociedad de Héctor Pérez Brignoli y Mario Samper, San José, FLACSO, 1994, pp. 55-82; "Los límites del poder en la era de Barrios". En Identidades nacionales y Estado moderno en Centroamérica, compilado por Arturo Taracena A. y Jean Piel, San José, Editorial de la Universidad de Costa Rica, 1995, pp. 87-96.

(1995-1998) Armando. González, Luis. “¿Qué es la sociedad civil y cuáles son sus desafíos fundamentales en El Salvador", ECA, marzo, 1995, pp. 252-256; "Sociedad y cultura en El Salvador", ECA, enero-febrero, 1996; "El Salvador en la postguerra: de la violencia armada a la violencia social", Realidad, septiembre-octubre, 1997, pp. 441-258; El Salvador. Violencia y sociedad (en coautoría con José Miguel Cruz), San Salvador, CIDAI-IUDOP, 1997; "Raíces sociales de la violencia: el aporte del marxismo", Realidad, julio-agosto, 1998, pp. 313-324. 
(1996) Lindo, Ricardo. Tierra (novela), San Salvador, Dirección de Publicaciones e impresos, 1996.

(1996) Alvarenga, Patricia. Cultura y ética de la violencia. El Salvador 18801932, San José, EDUCA, 1996.

(1996) Cardenal, Rodolfo. Manual de historia de Centroamérica, San Salvador, UCA Editores, 1996.

(1996) Taracena Arriola, Arturo. Periódicos salvadoreños de la primera mitad del siglo XIX (seleccionados por A.TA.), San Salvador, Fundación "Dr. Manuel Gallardo"/Centro de Estudios Mexicanos y Centroamericanos, 1996.

(1996) Roberto; Rubio Fabián, German, Anne y Góchez, Roberto. La situación ecológica de El Salvador en cifras, San Salvador, UCA Editores, 1996.

(1997) Walter, Knut. Las fuerzas Armadas y el Acuerdo de Paz. La transformación necesaria del ejército salvadoreño, San Salvador, FLACSO/Fundación Friedrich Ebert Stiftung, 1997.

(1997) Ribera, Ricardo. Pinceladas para un cuadro de la transición. Artículos, análisis de coyuntura y comentarios entre 1991 y 1996, San Salvador, Ediciones para el Debate, 1997.

(1997-1998) Molina Velásquez, Carlos. Novela, arraigo y nihilismo, Cultura, 80, 1997, pp. 166-169; "Crítica literaria y crítica de la realidad", Cultura, 82, 1998, 175-187; "El demonio de la paz", Realidad, 66, 1998, pp. 633-647.

(1998) Cruz, José Miguel y Portillo Peña, Nelson. Solidaridad y violencia en las pandillas del gran San Salvador. Más allá de la vida loca, San Salvador, UCA Editores, 1998.

(1998) Papadopoulos, Renos. Violencia en una sociedad en transición, del Programa de las Naciones Unidas para el Desarrollo (PNUD), San Salvador, 1998.

(1998) García-Nieto París, María Carmen. Historia del tiempo presente en El Salvador y memoria oral, Realidad, Revista de Ciencias Sociales y Humanidades, 64, 1998, pp. 401-416.

(1998) Krämer, Michel. El Salvador, Unicornio de la Memoria, San Salvador, Ediciones Museo de la Palabra, 1998.

(1999) Bello Suazo, Gregorio. Identidad nacional y memoria colectiva. Elementos para su discusión. En Oscar Martínez Peñate, El Salvador. Sociología General, op. cit, 1999, pp. 55-66.

Por otra parte, se debe agregar la investigación y elaboración de ciertas tesis de licenciatura en psicología, de la Universidad Centroamericana "José Simeón Cañas" (UCA), centradas en el estudio de la identidad nacional salvadoreña o relacionados con ella. Tres de estas tesis son: 
La estratificación social y su influencia en la autoimagen, de Mirian Turcios y Marta Velásquez de Suarez, Tesis de licenciatura en psicología, Universidad Centroamericana "José Simeón Cañas", Facultad de Ciencias del Hombre y de la Naturaleza, San Salvador, 1981

Autoimagen del adulto joven salvadoreño. Estudio comparativo entre obreros y universitarios de ambos sexos en la ciudad de San Salvador, de Ana Villavicencio de Fernández y otros. Tesis de licenciatura en psicología. Universidad Centroamericana "José Simeón Cañas", Facultad de Ciencias del Hombre y de la Naturaleza, San Salvador, 1986.

La identidad nacional del salvadoreño, de Silvia Eleonor Azucena Mayorga y otros (Asesorada por Martín-Baró). Tesis de licenciatura en psicología. Universidad Centroamericana "José Simeón Cañas", Facultad de Ciencias del Hombre y la Naturaleza, San Salvador, 1989.

Y para tener una visión más amplia sobre la identidad nacional salvadoreña, que se enmarca dentro de una realidad e identidad histórica y cultural precolombina, centroamericana, indo-a fro-latinoamericana e iberoamericana, se recomiendan y nombran ciertos textos básicos:

Popol Vuh. Las antiguas historias del Quiche (Es uno de los más hermosos documentos de la literatura oral pre-hispánica. Presentación de Rafael Rodríguez Díaz), San Salvador, UCA Editores, 1980.

I libro de los libros de Chilam Balam (Aunque redactado después de la conquista, recoge las fases culturales por las que pasó el pueblo maya de Yucatán), México, FCE, 1979.

Memorial de Sololá (Memorial de tecpan-Atitlán). Anales de los Cakchiqueles. Título de los señores de Totonicapán (Edición de Adrián Recinos), México, FCE, 1950.

Crónicas indigenas. Visión de los vencidos (Edición de Miguel León-Portilla), Madrid, Historia 16, 1985.

(1922-1928) Kruckeberg, Walter. Etnología de América, México, FCE, 1982; Mitos y leyendas de los aztecas, incas, mayas y muiscas, México, FCE, 1985.

(1956-1992) León-Portilla, Miguel. Filosofía Nahuatl, México, Instituto Indigenista Interamericano, 1956; El reverso de la conquista, México, Editorial Joaquín Mortiz, 1963; Toltecayotl. Aspectos de la cultura náhuatl, México, FCE, 1992.

(1957-1998) Zea, Leopoldo. América en la historia, Madrid, Revista de Occidente, 1957; La filosofía americana como filosofía sin más, México, Siglo XXI, 1969; Filosofía de la historia americana, México, FCE, 1978; El pensamiento latinoamericano, Barcelona, Ariel, 1965; "Desarrollo de la crea- 
ción cultural latinoamericana". En Cultura y creación intelectual en América Latina, coordinado por Pablo González Casanova, México, Siglo XXI, 1984, pp. 213-234; América Latina en sus ideas, coordinado e introducido por Lepoldo Zea, México, UNESCO/Siglo XXI, 1986; Fuentes de la cultura Latinoamericana, coordinado por Leopoldo Zea (tres tomos), México, FCE, 1993; “Cultura occidental y culturas marginales". En David Sobrevilla, Filosofía de la cultura, Madrid, Ed. Trotta, 1998.

(1961) Torres Rivas, Edelberto. Interpretación del desarrollo social centroamericano (1' edición, Santiago, Editorial PLA, América Nueva, Chile, 1969), San José, EDUCA, 1981.

(1963) Lipschutz, Alejandro. El problema racial en la conquista de América (prólogo de Pablo Neruda), México, Siglo XXI, 1975 (3ª edición).

(1972) Martínez Peláes, Severo. La patria del criollo. Ensayo de interpretación de la realidad colonial guatemalteca, San José, EDUCA, 1972.

(1972) Fernández Moreno, César (coordinador). América Latina en su literaıura, México, UNESCO, 7 Siglo XXI, 1972.

(1974-1986) Galeano, Eduardo. Las venas abiertas de América Latina, México, Siglo XXI Editores, 1974; Memorias del fuego (tres tomos), Madrid, Siglo XXI de España, 1982, 1984 y 1986.

(1976) Baudot, Georges. Las Letras Precolombinas, México, Siglo XXI Editores, 1979 ( 1 ‘ edición en español).

(1977) Moreno Fraginals, Manuel (relator). África en América Latina, México, UNESCO, Siglo XXI, 1987.

(1977-1985) Cardoso, Ciro F. S. y Pérez Brignoli, Héctor. Centroamérica y la economía occidental, San José, Editorial Universidad de Cosia Rica, 1977; Ilistoria económica de América Latina (dos tomos), Barcelona, Editorial Crítića, 1979; Pérez Brignoli, l léctor. Breve historia de Centroamérica, Madrid, Alianza Editorial, 1985.

( $(981-1991)$ Bonfil Batalla, Guillermo. Utopía y revolución. El pensamiento político contemporáneo de los indios en América Latina, México, Editorial Nueva Imagen, 1981; "La nueva presencia política de los indios: un reto a la creatividad latinoamericana". En Cultura y creación intelectual en América latina, op. cit. pp. 141-1.58, 1984; Pensar la cultura, México, Alianza, 1991.

(1982) Lásciaris, Constintino. Ilistoria de las ideas en Centroamérica, San José, EDUCA, 1982.

(1984) González Casanova, Pablo (coordinador). Cultura y creación intelectual en América Latina, México, UNAM/Universidad de las Naciones Unidas/Siglo XXI, 1984. 
(1986) Yurkievich, Saúl (compilador). Identidad cultural de Iberoamérica en su literatura, Madrid, Editorial Alhambra, 1986.

(1986-1991) Mires, Fernando. En nombre de la cruz. Discusiones teológicas y poltticas frente al holocausto de los indios (periodo de la conquista), San José, DEI, 1986; La colonización de las almas. Misión y conquista en Hispanoamérica, San José, DEI, 1987; El discurso de la indianidad. La cuestión indigena en América Latina, San José, DEl, 1991.

(1987-1990) García Canclini, Néstor. Políticas culturales en América Latina, México, Ed. Grijalbo, 1987; Culturas hibridas. Estrutegias para entrar y salir de la modernidad, México, Ed. Grijalbo, 1990.

(1987) Martín-Barbero, Jesús. De los médios a las mediaciones. Comunicación, cultura y hegemonia, México, Ed. Guslavo Gili, 1987.

(1988) Fernández V., Rodrigo. y Lungo Uclés, Mario (compiladores). La estructuración de las capilales centroamericanas, San José, EDUCA, 1988.

(1988) Fabregal, C: Esteva. Lil mestizaje en Iheroamérica, Madrid, Edilorial Alhambra, 1988.

(1989) LaFeber, Walter. Revoluciones inevitables. La políica de Estados Unidos en Centroumérica, Sun Salvador, UCA Editores, 1989.

(1992) Robles, Laureano (editor). Filosunfía iberoumericana en la época del Encuentro, Madrid, Editorial Trolla, Enciclopedia Iberoamericana de Filoso[ía, 1992. (Obra en la que se analiza, entre otros: "El pensamiento nahuall", por Miguel León Portilla; "El pensamiento Maya" por Mereedes de la Garza; "El pensamiento incaico", por María Luisa Rivara de Tuesta; elc.)

(1993) Facultad Latinoamericana de Ciencias Sociales (FLACSO), Historia general de C'entroamérica (scis tomos), Madrid, Ediciones Sirucla, 19993 (2 edición, Sill José, FLACSO, 1994). M. Carmack, Robert (editor). I-Historia Antigua. Pinto Soria, Julio (editor). II-lil régimén colonial. Pérez. Brignoli, Héctor (editor). III- Dela Ilusiración al liberalismo. Acuñal Ortega, Viclor Hugo (editor). IV-Las repúblicas agroexportadoras. P'érez. Brignoli, Héctor. (editor). V- De la postguerra a la crisis. T'orres Rivas, Edelberto (editor). VILa historia inmediala.

(1994) Fornet-Betancourt, Raúl. Ilacia una filosofia intercultural latinoamericana, Säl José, DEI, 1994.

(1990) Fonsecia, Elizaheth. C'entroameirica: su historia, San José, FLACSO/ EDUCA, 1996.

(1996) Salvadora Ortiz, Marría (compiladora). Identidades y producciome's culturales c'n Amírica Latina, Colección Identidad Cultural, Editorial de la Universidad de Costa Rical, San José, 1996. 
(1997) Rojas Mix, Miguel. Los cien nombres de América. Eso que descubrió Colón, San José, Colección Identidad Cultural, Editorial de la Universidad de Costa Rica, 1997.

(1998) Sobrevilla, David (editor). Filosofía de la cultura, Madrid, Editorial Trotta, Enciclopedia Iberoamericana de Filosofía, 1998. (Obra en la que se analiza, entre otros: "El concepto cultura, sus temas fundamentales", por Miguel Reale; "Estructura y mecanismos de la cultura", por José Lorite Mena"; Identidad y dependencias culturales", por Horacio Cerutti Gulberg; etc.)

\section{Notas}

1. José María Mardones, "El neo-conservadurismo de los posmodernos". En Gianni Vattimo y otros, En torno a la posmodernidad, Barcelona, Anthropos. Editorial del Hombre, 1994, p.38.

2. Ver este rico debate en la obra del francés Jean-Francois Bayart, $L$ 'illusion identitaire, Paris, Fayard, 1996.

3. Enrique Guinsberg, "Los medios masivos y la construcción del modelo neoliberal de identidad". En Teresita Cordero y otros (compiladores), Dominación social y subjetividad. Contribuciones de la psicología Social, San José, Editorial de la Universidad de Costa Rica, 1996, pp. 187-200 (p. 187).

4. Ibidem., pp. 187-188.

5. Ignacio Martín-Baró, " ¿Trabajador alegre o trabajador explotado? La identidad nacional del salvadoreño", Revista de Psicología de El Salvador, 35, 1990, pp. 147-172.

6. Entrevista realizada a Antonio Gallo Armosino por el autor de este artículo, durante los cursos de Doctorado en Filosofía Iberoamericana de la UCA, durante el mes de noviembre de 1998.

7. David Miller (director), "Nacionalismo". En Enciclopedia del pensamiento político, Madrid, Alianza Editorial, 1989, p. 419.

8. Ernest Gellner, Naciones y nacionalismo, México, Consejo Nacional para la Cultura y las Artes/Alianza Editorial, 1991, p. 13.

9. Guillermo Bonfil Batalla, "La nueva presencia política de los indios: un reto a la creatividad latinaomericana". En Pablo González Casanova, Cultura y creación intelectual en América Latina, México, Siglo XXI, 1984, p. 141.

10. Maritza Montero, Ideología, alienación e identidad nacional, Universidad Central de Venezuela, Caracas, 1984, pp. 76-77.

11. Marvin Barahona, Evolución histórica de la identidad nacional, Tegucigalpa, Editorial Guaymuras, 1993, p. 13.

12. Véase Fernand Braudel, Las civilizaciones actuales. Estudio de historia económica y social, Madrid, Tecnos, 1983, pp. 34-46.

13. Rodolfo Stavenhagen, "La cultura popular y la creación intelectual". En Pablo González Casanova (coord.), Cultura y creación intelectual en América Latina, op. cit., p. 295.

14. Ibidem., pp. 295-296.

15. Claude Levi-Strauss, $L$ 'identité, Paris, Presses Universitaire de France, 1977, p. 8.

16. Citado por Leopoldo Zea, Cfr. Fin del siglo XX ¿Centuria perdida?, México, FCE, 1996, p. 39. No obstante, se aconseja leer Norberto Bobbio, Derecha e izquierda, 
Madrid, Taurus, 1995; Elogio de la templanza y otros escritos morales, Madrid, Temas de hoy, ensayo, 1997.

17. Jürgen Habermas, Identidades nacionales y postnacionales, Madrid, Tecnos, 1989; Más allá del Estado nacional, Madrid, Ed. Trotta, 1997; Facticidad y validez. Sobre el derecho y el estado democrático de derecho en términos de teoria del discurso, Madrid, Ed. Trotta, 1998.

18. Por problema filosófico existencial entendemos las preguntas que se plantea toda persona ante su realidad personal, social y cultural. Pues consideramos que si bien no todo ser humano está llamado a ser filósofo o a hacer filosofía, sí lo está en cambio por naturaleza a filosofar. El filosofar no es, pues, algo exclusivo de los filófosos. Todo aquel que asume, ante cualquier problema, cosa o situación una actitud crítica, ética o radical está por ende filosof ando.

19. Raúl Fornet-Betancourt, "La conquista: ¿una desdicha histórica? Una aproximación al problema desde José Martí". En Guillermo Melćndez (editor), Sentido histórico del V centenario (1492-1992), San Josć, DEI, 1992, p. 186.

20. Cfr. Luis Ferrero, ¿Porqué prehistoria si hay historia precolombina?, San Josć, Universidad Estatal a Distancia, 1986, p. 36.

21. Ibidem., p. 36.

22. Raúl Fornet-Betancourt, op. cit., p. 186-187.

23. Una obra clave sobre los "pueblos de indios" es la del historiador guatemalteco Severo Martínez Peláez, La patria del criollo, San José, EDUCA, 1972, pp. 441570.

24. Una definición sobre el término ladino: "Al principio, indígena que hablaba espanol. A fines del siglo XVII y en el siglo XVIII el término se usó para designar a individuos de origen indio que habían perdido todo nexo con sus comunidades y por lo tanto no eran, culturalmente hablando indígenas. La ladinización favoreció el mestizaje". En Julio Pinto Soria, Historia General de Centroamérica, El régimen colonial, Tomo II, Glosario, San Josć, FLACSO, 1994, p. 325.

25. Sobre la sociedad colonial puede consultarse Julio Pinto Soria, Historia General de Centroamérica, El régimen colonial (Tomo II), op. cit.

26. Simón Bolívar, Escritos políticos, Madrid, Alianza Editorial, 1983, p. 69-70.

27. Citado por Leopoldo Zea, en "Desarrollo de la creación cultural latinoamericana", p. 217. En Pablo González Casanova, Cultura y creación intelectual en América Latina, México, Siglo XXI, 1984.

28. Ibidem, pp. 217-218.

29. Entrevista realizada a Alejandro Serrano Caldera por el autor de este artículo, durante los cursos de Doctorado en Filosofía Iberoamericana de la Universidad Centroamericana "José Simeón Cañas", en el mes de abril de 1999.

30. Un gran esfuerzo en esta línea lo constituyen las obras editadas por Stefan Roggenbuck y Rafacl Guido Bćjar: Cultura y desarrollo en El Salvador, San Salvador, Fundación Konrad Adenauer, 1994; y también El Salvador a fin de siglo, San Salvador, Fundación Konrad Adenauer, 1995.

31. Remito al lector a la introducción que hace Amalio Blanco, "La coherencia en los compromisos", en el libro de Ignacio Martín-Baró, Psicologia de la liberación, Madrid, Editorial Trotta, 1998, pp. 9-36.

32. Ibidem. 
33. Maritza Montero, "Rctos y perspectivas de la psicología de la libcración. Consideracioncs a finales de siglo". Conferencia magistral impartida en cl primer Congreso Internacional sobrc Psicología de la Libcración, cclcbrada en Mćxico, del 16 al 18 de novicmbre de 1988, y reproducida en ECA, 601-602, 1999, pp. 1123-1135.

34. Véase I. Martín- Baró, "Los grupos con historia: un modelo psico-social", Boletín de la AVEPSO, XI (1), 1988, pp. 3-18

35. Véase Fals Borda, Acción comunal en una vereda colombiana, Bogotá, Univcrsidad Nacional, Monografías sociológicas, 1959.

36. Véase Ignacio Martín-Baró, “I. El fatalismo como identidad cognitiva”. En I. Martín-Baró, Psicología de la liberación, op. cit., pp. 39-128.

37. Véase A. Rodrígucz, Introducción a la Psicología Social, Petrópolis, Vozes, 1972.

38. Maritza Montcro, op. cit., p. 1128.

39. Ignacio Martín-Baró, "El papel desenmascarador del psicólogo". En Psicología de la liberación, op. cit., pp. 167-168.

40. Ibidem, pp. 169-170.

41. Ibid, pp. 170-171.

42. Ibid., p. 171.

43. Ibid., p. 171.

44. Una obra clave de Martín-Baró, y de reciente publicación, cs la anteriormente citada Psicología de la liberación, cuyos capítulos son un conjunto de artículos seleccionados por Amalio Blanco. En efecto, Blanco llevó a cabo la edición, introducción y notas de este valioso libro. Desde su introducción, y a lo largo de todas las notas que al pie de página acompañan los textos de Martín-Baró, Blanco proporciona un conjunto ordenado de inapreciables conocimientos sobre la vida y la obra de cste gran psicólogo social nacido en España pcro salvadorcño de corazón y opción. Los artículos fundamentales para cl cstudio de la identidad latinoamericana y salvadoreña que en este texto sc recogen son: I. "El fatalismo como identidad cognitiva", que encabeza el primer capítulo del libro, y que se compone de: 1 . Presupuestos psicosociales del carácter, 2. El latino indolente, 3. El Latino explotado. Los otros matcriales que conforman cl libro, a partir del capítulo II, y scguidos por cl III y IV, son los siguicntes. En cl II, que lleva por título "El quchacer desidcologizador de la psicología", se encuentran: 4. Conscientización y currículos universitarios, 5. El papel desenmascarador del psicólogo. En el III, con el título "La liberación como vivencia de la fe", figuran: 6. Iglesia y revolución en El Salvador, 7. Religión y guerra psicológica, 8. Dcl opio religioso a la fe libertadora. Y en el IV, que se titula "La liberación como exigencia de la praxis", cstán: 9. Hacia una psicología de la liberación, 10. La liberación como horizonte de la psicología. Y cl cpílogo de "El contexto socio-político del asesinato de Ignacio Martín-Baró: Noam Chomsky". Por tanto, Psicología de la liberación no sólo es una labor académica de rescatc y revalorización de la obra cicntífica-filosófica de Martín-Baró, que Blanco llcva a cabo muy profesionalmente como psicólogo y editor, sino tambićn es un homenaje suyo para la maravillosa persona que fuc Nacho, su "amigo inolvidable". Pcro, asimismo, con Psicología de la liberación Amalio Blanco hace un significativo regalo para cl pucblo salvadorcño, en gencral, y para la comunidad universitaria de la UCA, en particular, por lo que en cste décimo aniversario de nuestros mártircs, le rcitcramos nucstro profundo agradecimicnto.

45. Jon Sobrino, "Ignacio Ellacuría, cl hombre y cl cristiano. Bajar de la cruz al pucblo crucificado (I)", Revista Latinoamericana de Teologia, 32, 1994, pp. 131-161 (p. 133). 
46. Ignacio Martín-Baró, Acción e ideologia. Psicologia social desde Centroamérica, UCA Editores, San Salvador, 1988, p. VIII.

47. "Editorial", ECA, 503, 1990, pp. 705-729.

48. Véase la revista $E C A$ dedicada a la of ensiva de noviembre: $E C A, 495-496,1990$, pp. 3-124

49. Roque Dalton fue fusilado el 10 de mayo de 1975, en El Salvador, por el Ejćrcito Revolucionario del Pueblo (ERP), acusado de "colaborar con el enemigo de clase". Cfr. Italo López Vallecillos, en Taberna y otros lugares, de Roque Dalton (introducción). En Roque Dalton, Taberna y otros lugares, San Salvador, UCA Editores, 1983.

50. Véase A. Herrera y Martín-Baró, "Ley y orden en la vida del mesón", ECA, 360, 1978, pp. 803-829

51. Amalio Blanco, op. cit., nota 1, Capítulo I, p. 39.

52. Ignacio Martín-Baró, "Hacia una Psicología de la liberación", Boletin de Psicologia, 22, 1986, pp. 219-231.

53. Ignacio Martín-Baró, Psicología de la libercación, op. cit., p. 104.

54. Ibidem., p.104.

55. Ibid., p. 105.

56. Ibid., p. 105.

57. Ibid., p.105.

58. Ibid., pp. 105-106.

59. ¡Ojalá se siguiera el ejemplo de lo que se hizo en otros países centroamericanos! En Nicaragua, el Banco Nicaragüense (BANIC), en 1974, resolvió la creación del "Fondo Cultural del Banco de América", con el fin de dar a su país un magnífico aporte documental y un valioso apoyo a la cultura nacional. Sí, creó una colección de publicaciones sobre estudios de historia, literatura, arqueología y otras ramas de la vida nacional con proyecciones internacionales. La producción hasta 1982 había alcanzado 48 títulos. Y en los años noventa, reinició sus publicaciones con doce títulos de la Serie Histórica. Pues, su objetivo, antes de ser privatizado, era "promover y desarrollar los valores culturales de Nicaragua" y "formar colecciones de obras de carácter histórico, literario, arqueológico y de cualquier naturaleza, siempre que contribuyeran a enriquecer el patrimonio cultural de la nación", con ediciones académicas y bellas y a precios realmente accesibles a estudiantes e intelectuales. Véase como ejemplo la obra de Tomas Ayon, que es parte de la Serie Histórica, Historia de Nicara. gua (tres tomos), Managua, Colección Cultural, Banco de Nicaragua, 1993.

60. Mario R. Vázquez, Bibliografia historiográfica de El Salvador, San Salvador, 1993 (inédito).

61. Ignacio Ellacuría, "Análisis ético-filosófico del proceso de diálogo en El Salvador". En I. Ellacuría, Veinte años de historia en El Salvador. Escritos politicos (1969. 1989), Tomo III, op. cit. p. 1393.

62. María Carmen García-Nieto París, "Historia del tiempo presente en El Salvador y memoria oral", Realidad, 64, 1998, pp. 401-116 (p. 402).

63. David Escobar Galindo, "Un pais que se niega a rccordar", Tendencias, 43, 1995, p. 14.

64. Guillermo Bonfíl Batalla, "La nueva presencia política de los indios: un reto a la creatividad latinoamericana", op. cit., p. 145.

65. Marvin Barahona, Evolución histórica de la identidad nacional, op. cit., p. 14. 
66. Véase la definición de cultura que hemos dado al final del punto primero de este artículo, siguiendo al sociólogo $R$. Stavenhagen.

67. En el año 1997, el cntonces Gobicrno de la República de El Salvador formó la Comisión Nacional de Desarrollo, integrada por seis personas procedentes de distintas profesiones y tendencias políticas, con cl propósito de crear un Plan de Nación. Para lograrlo, la Comisión presentó cl 16 de encro de 1998, las Bases para el plan de nación. Estc documento sirvió de apoyo a un Grupo Gestor, nombrado por la Comisión, para rcalizar una scric de consultas ciudadanas, en principio rcalizadas en todo el país y supuestamente en la mayoría de sectores sociales y culturales durante esc año, con el fin de tomar en cuenta las realidades y necesidades sociales, políticas, cconómicas y culturales de la población, respecto al presente y futuro de la vida nacional. Luego, en cncro de 1999, la Comisión hizo público el texto Temas clave para el plan de nación. Consulta especializada. En esta obra intervinieron 211 personas, aparentemente cspecialistas provenientes de distintos campos y profesiones, en la que scñalan los posibles caminos a seguir para montar una cstrategia nacional de desarrollo para cl siglo XXI. Luego de 29 mescs de trabajo, la Comisión cntregó al nucvo gobicrno, cl 21 de octubre de 1999, cl documento: Acciones iniciales del plan de nación. El presidente Flores sc ha comprometido a impulsar estc proyecto que "busca enrumbar al país bajo los lincamientos de la descentralización, la reconversión productiva y la integración con la región centroamcricana", scgún la noticia difundida por La Prensa Gráfica, cl día 22 de octubre de 1999.

68. Comisión Nacional de Desarrollo, Bases para el plan de nación, San Salvador, 1998, pp. 1-12.

69. Ibidem., p. 12.

70. "Flores presenta of erta cultural" (redactado por Rafacl García, coordinador de nacionalcs), La Prensa Gráfica, 19 de febrero de 1999.

71. Francisco Javier Ibisate, "Lecciones y aplicaciones del plan de nación", Realidad, 63, 1998, 219-241, p. 219.

72. Véasc Ernesto Wauthion, "Ética y desarrollo: propucsta para su relación y para un desarrollo sostenible desde una filosofía liberadora", cn VV. AA. Para una filosofía liberadora. Primer Encuentro Mesoamericano de Filosofia (1994), San Salvador, UCA Editorcs, 1995, pp. 231-247. Tambićn del mismo autor: "Crítica a la postmodernidad y al ncolibcralismo. Una aproximación al pensamiento de Franz J. Hikclammert", Realidad, 62, 1998, pp. 157-184.

73. "El país ha dejado de ser suclo y lo hemos convertido en piso", es una frase prestada a nucstro qucrido amigo y colcga de la UCA, el pocta y cscritor Rafael Rodrígucz Díaz.

74. Comisión Nacional de Desarrollo, Temas claves para el plan de nación. Consulta especializada, San Salvador, 1999.

75. Comisión Nacional de Desarrollo, Acciones iniciales del plan de nación, San Salvador, 1999.

76. Para un análisis crítico sobrc las Bases para el plan de nación, remito al lector a los siguientes autores y sus escritos: Francisco Javier lbisate, "Lecciones y aplicaciones del Plan de nación"; Luis Armando González, "La pobreza cstructural en la bases para cl plan de nación"; Carlos Molina Velásquez, "Poćtica y utopía. Una lectura crítica de las bases para cl plan de nación". Artículos cscritos en la revista Realidad, 63, mayo-junio, 1998. Consúltesc tambićn CIDAI, "Evaluación crítica de las bascs 
para el plan de nación"; Francisco Javier Ibisate y otros, "Diálogo con las bases para el plan de nación. Las Sociedades prósperas son las que existen en función del ser humano”, y Carlos Molina Velásquez, “iMoral provinciana o ética global?”. Artículos escritos en ECA, 594, abril, 1998.

77. Francisco Javier Ibisate, op., cit., p. 219.

78. Comisión Nacional de Desarrollo, Acciones iniciales del plan de nación, op. cit., p. 3.

79. Ignacio Martín-Baró, Acción e ideología. Psicología social desde Centroamérica, San Salvador, UCA Editores, 1983, p. 121.

80. Ibidem., p. 117.

81. Antonio Gallo Armosino, Identidad nacional, Guatemala, Universidad Rafael Landivar, 1994, p. 15.

82. Boletín de la Camara Alemana-Salvadoreña de Comercio e Industria, 58, julioagosto, 1999, p. 3.

83. Herman W. Bruch, “¿Hemos perdido la verguenza?”, El Diario de Hoy, martes 5 de octubre de 1999.

84. Lito Montalvo, “¡Vendo exámenes de la PAES!”, El Diario de Hoy, 10 de octubre de 1999.

85. Emesto Valiente Durán, Crónicas de actualidad. “¡Son los intereses, maje!”, La Prensa Gráfica, 14 de octubre de 1999.

86. “Editorial”, La Prensa Gráfica, 19 de agosto de 1999.

87. Carlos Umaña Cerna, Punto de vista. Enfoques. "Una comparación. El puente de Brooklyn y el Hermano Lejano", La Prensa Gráfica, 1 de agosto de 1999.

88. Roberto Turcios, Zona Abierta. "Enfermedades del 2000", La Prensa Gráfica, 12 de octubre de 1999.

89. Miguel Huezo Mixco, Pre Textos. "El desencanto", La Prensa Gráfica, 9 de septiembre de 1999.

90. Adela Cortina, Ética civil y religión, Madrid, PPC, 1995, p. 21.

91. Roxana Huezo, entrevista: "La corrupción está en todos los niveles: Quintanilla Schmidt", El Diario de Hoy, 10 de octubre de 1999.

92. Ibidem.

93. Véase al respecto el artículo de Carlos Molina Velásquez, “¿Moral provinciana o ética global?", ECA, 594, 1998, pp. 383-388.

94. José María Mardones, Capitalismo y religión. La religión política neoconservadora, Santander, Sal Terrae, 1991.

95. Roberto Turcios, Zona abierta, "Reyes de la improvisación", La Prensa Gráfica, 19 de octubre de 1999.

96. "Abogados dicen que es inconstitucional exigir leer la biblia en las escuelas. Rechazan lectura bíblica en aulas", La Prensa Gráfica, 26 de octubre de 1999.

97. Roberto Turcios, Zona abierta. "Crítica sin adjetivos", La Prensa Gráfica, 5 de octubre de 1999.

98. Ibídem.

99. Véase José Luis L. Aranguren, "Prólogo". En Fernando Velasco, La esperanza como compromiso, Estella (Navarra), Editorial Verbo Divino, 1990, p. 8.

100. Adela Cortina, op. cit., p. 20.

101. Ernst Bloch, "El hombre como posibilidad". En E. Bloch y otros, El futuro de la esperanza, Salamanca, Ediciones Sígueme, 1973, pp. 71-75. 
102. Fernando Aínsa, "El desafío de la identidad múltiple en la sociedad globalizada". En Fronteras $e$ identidodes, Escuela de Estudios Generales/Comunicación y lenguaje/ Universidad de Costa Rica, Editorial de la Universidad de Costa Rica, San José, 1998, pp. 19-35 (p. 20-21).

103. Frase del ensayista tunesino Albert Memmi. Citado por Aínsa, op. cit., p. 20.

104. Raúl Fornet-Betancourt, Hacia una filosofía inercultural latinoomericana, San José, DEI, 1994, p. 34.

105. Ibidem., p. 13.

106. Ibid., p. 13. 